\title{
CARACTERES SILVICULTURAIS E CONTEÚDO DE NUTRIENTES \\ NO FOLHEDO DE ALGUNS POVOAMENTOS PUROS \\ E MISTO DE ESPÉCIES NATIVAS
}

\author{
MARCO ANTONIO DE OLIVEIRA GARRIDO
}

Orientador: FABIO POGGIANI 
ii.

A meus pais e irmãos,

dedico.

A Leda,

à clāudia,

à Paula,

à Cássia,

ofereço . 


\section{AGRADECIMENTOS}

Ao Instituto Florestal que autorizou a minha participação no curso de pós-graduação em Engenharia Florestal.

Ao Conselho Nacional de Pesquisas - CNPq, pela bôlsa concedida nos anos de 1976 e 1977 .

Um agradecimento especial deve ser registrado ao Professor Fabio Poggiani, pela dedicação, boa vontade e pa ciência na orientação dessa dissertação.

A todos indistintamente que concorreram para a realização desse trabalho. 


\section{INDICE}

Pāgina

RESUMO

vii

SUMMARY

$x i$

1. INTRODUÇÃO

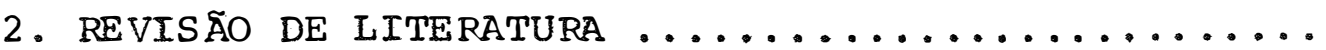

2.1 Formação de povoamentos florestais com essências nativas $\ldots \ldots \ldots \ldots \ldots \ldots \ldots \ldots$

2.2 Experimentos com essências nativas ........

2.3 Consideraçôes ecolögìcas sobre o estudo do





2.5 Formação da serapilheira ...............

2.6 Composição da serapilheira .............

2.7 Efeitos da floresta sobre as condições edā-

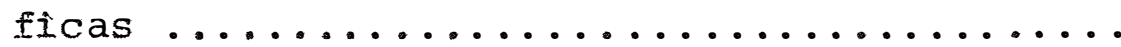

2.8 Variações encontradas na metodologia ......

2.8.1 Caracteres silviculturais ..........

2.8.2 Avaliação da deposição de matéria or-

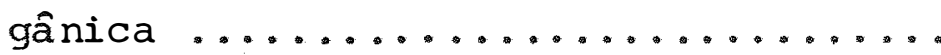

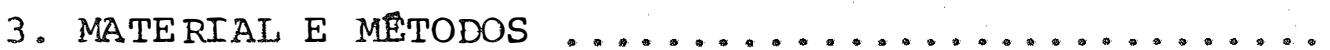

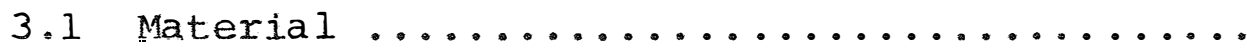

3.1.1 Localização e topografia ...........

3.1 .2 clima $\ldots \ldots \ldots \ldots \ldots \ldots \ldots \ldots \ldots \ldots \ldots \ldots \ldots \ldots \ldots \ldots \ldots$

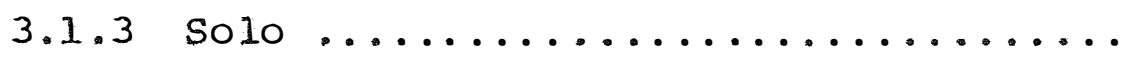


Pāgina

3.1.4 Diagrama climático ............. 35

3.1.5 Vegetação primitìva ............ 37

3.1.6 Essências florestaìs usadas ........ 37

3.1.7 Descrição das espëcies ........... 38

3.1.8 Instalação do experimento .......... 42

3.2 Mẻtodos ........................... 43

3.3 Roteiro da pesquisa e experimentação ....... 45

4. RESULTADOS ........................... 47

4.1 Crescimento ...................... 47

4.2 Deposição das folhas ................. 56

4.3 Variação dos elementos quimicos das folhas deciduas nos povoamentos florestais ....... 65

5. DISCUSSÃO DOS RESULTADOS .................... 70

5.1 Caracteristicas silviculturais e dendrométri

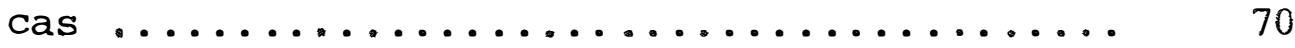



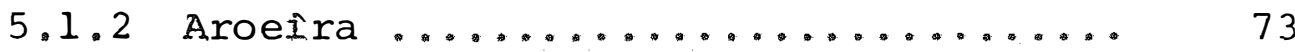

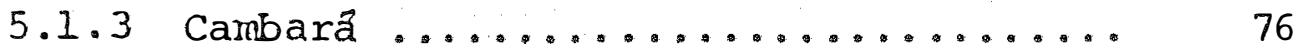

5.1 .4 Ipê-roxo $\ldots \ldots \ldots \ldots \ldots \ldots \ldots \ldots \ldots \ldots$

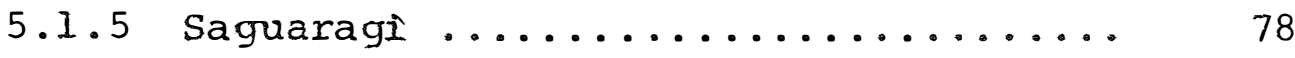

5.2 Deposição das folhas ................. 80

5.3 Concentração de nutrientes das folhas deposi



5.4 Povoamentos florestais puros e mistos ...... 88

5.5 Considerações finnais ................... 90 
Página

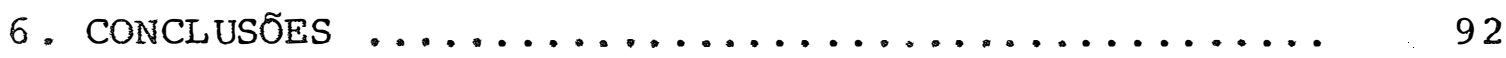

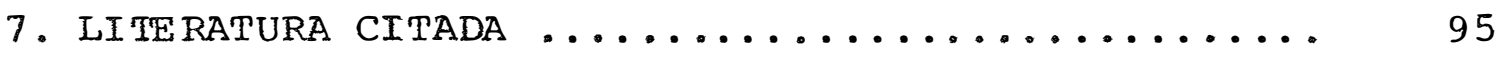


CARACTERES SILVICULTURAIS E CONTEUDDO DE NUTRIENTES NO FOLHEDO DE ALGUNS POVOAMENTOS PUROS E MISTO DE ESPECIES NATIVAS

\author{
MARCO ANTONIO DE OLIVEIRA GARRIDO \\ Orientador: FABIO POGGIANI
}

RESUMO

Foram estudadas as características silviculturais de cinco espécies indígenas plantadas em povoamentos flo restais puros e misto. Determinou-se também a quantidade de folhas e nutrientes depositada no solo.

o experimento foi instalado em dezembro de 1970 na Estação Experimental de Assis, do Instituto Florestal, da Secretaria de Agricultura e Abastecimento do Estado de São Paulo. 
o delineamento estatístico escolhido foi o de Blocos ao Acaso, contendo seis tratamentos e quatro repeti Ções. As espécies estudadas foram as seguintes: angico - Anadenanthera falcata (Benth) Brenan; aroeira - Astronium urun deuva Engl.; cambará - Gochnatia polymorpha (Less.) Cabr.; ipê-roxo - Tabebuia impetiginosa (Mart.) Tol. e saguaragi Colubrina rufa Reiss, as quais constituiram cinco tratamentos, e o sexto foi formado pela consociação dessas espécies formando o povoamento misto.

A altura e O DAP das árvores foram medidos anual mente a partir de 1972, visando acompanhar o ritmo de crescimento das espécies em estudo.

Durante o ano de 1977 coletaram-se mensalmente, as folhas que se depositaram no solo, por meio de caixas cole. toras, especialmente distribuídas nos vários povoamentos.

o crescimento em diâmetro das diferentes espécies obedeceu à seguinte ordem decrescente: Anadenanthera fal cata (Benth) Brenan, Gochnatia polymorpha (Less.) Cabr., Astronium urundeuva Engl., Colubrina rufa Reiss e Tabebuia impetiginosa (Mart.) Tol.

Colubrina rufa Reiss destacou-se das demais pelo fuste retilíneo, apresentando excelente derrama natural 
mas foi susceptível à geada, a qual afetou drasticamente o seu crescimento dendrométrico.

Anadenanthera falcata (Benth) Brenan cuja forma è pior do que a da Colubrina rufa, apresentou o crescimento mais rāpido dentre as espēcies estudadas e se mostra como promissora para o plantio em solos de cerrado.

o incremento médio anual, de cada espécie, observado pode ser visto a seguir:

$$
\text { Espēcie. }
$$

Anadenanthera falcata

Gochnatia polymorpha

Astronium urundeuva

Colubrina rufa

Tabebuia impetiginosa

$$
\frac{\mathrm{DAP}}{\mathrm{cm} / \mathrm{ano}}
$$

$\frac{\text { Altura }}{\mathrm{m} / \mathrm{ano}}$

1,42

0,99

1,08

0,70

0,93

0,80

0,66

0,68

0,62

0,53

Não foi constatada a influência da consociação das espēcies sobre o ritmo de crescimento nos povoamentos pu ros e no misto.

A maior deposição de folhas no solo, ocorreu no povoamento do cambará $(4751 \mathrm{~kg} / \mathrm{ha} / \mathrm{ano})$ seguido pelos povoamen tos do angico (4381 kg/ha/ano); misto (2616 kg/ha/ano); aroei 
ra (2297 kg/ha/ano) e do ipê-roxo (980 kg/ha/ano).

A análise de nutrientes das folhas decíduas mos trou uma maior concentração de nitrogénio no angico (2,06 \%); potássio $(1,34 \%)$ e magnésio $(0,30 \%)$ no cambará e de cálcio $(1,89$ \%) no ipê-roxo. O teor de fósforo $(0,05$ a 0,08 \%) encon trado foi praticamente igual em todos os povoamentos estudados.

As espēcies mostraram um comportamento bem dife renciado quanto à época de deposição de folhas e somente a aroeira apresentou uma deposição de folhas nitidamente mais acentuada no período seco.

Do ponto de viṣta ecológico, a queda uniforme das folhas durante o ano, verificado no povoamento misto propicia uma proteção mais efetiva do solo. 
SILVICULTURAL PATTERNS AND LEAF FALL NUTRIENT CONTENT IN SEVERAL NATIVE SPECIES GROWING IN PURE AND MIXED STANDS MARCO ANTONIO DE OLIVEIRA GARRIDO Graduate student

FÁBIO POGGIANI

Adviser

SUMMARY

Silvicultural patterns and leaf fall nutrient content of five native species growing in pure and mixed stands were studied in an experiment trial carried out at Assis Forest Experiment Station of the são Paulo state Forest Institute. 
The native species: Anadenanthera falcata (angi co), Astronium urundeuva (aroeira), Gochnatia polymorpha (cam bará), Tabebuia impetiginosa (ipê-roxo) and Colubrina rufa (saguaragi) were planted in december 1970, performing five pure and one mixed stands. The mixed stand included all the species growing in pure stands.

Tree growth patterns were observed until 1980 and leaf fall was monthly collected by several traps randomly distributed on the forest floor of the stands during 1977. Growth data including D.B.H. and height increments of the trees (10 years old) in the different stands are presented in the following table.

Species $\quad \frac{\text { D.B.H. }}{\mathrm{cm} / \text { year }} \frac{\text { Height }}{\mathrm{m} / \text { year }}$
A. falcata
1.42
0.99
G. polymorpha
1.08
0.70
A. urundeuva
0.93
0.80
C. rufa
0.66
0.70
T. impetiginosa
0.62
0.53
Mixed stand
1.07
0.80

Average height and D.B.H. of the trees growing in the mixed stand were not significantly different from the averages of trees growing in pure stands. 
The highest annual leaf fall was observed in $G$. polymorpha stand $(4751 \mathrm{~kg} / \mathrm{ha})$ followed by $A$. falcata $(4381$ $\mathrm{kg} / \mathrm{ha})$, mixed (2616 kg/ha), A. urundeuva $(2297 \mathrm{~kg} / \mathrm{ha})$ and $T$. impetiginosa $(980 \mathrm{~kg} / \mathrm{ha})$.

The highest concentration of nitrogen was found in the leaf fall of $A$. falcata, while $G$. polymorpha showed the highest concentration of potassium and magnesium (1.34 \% and $0.30 \%)$, calcium was more concentrated in the leaf fall of T. impetiginosa. Phosphorus concentration in the leaf fall was similar in all the stands.

It was also observed different patterns of leaf fall. over the year in each stand. However, only in the $A$. urundeuva stand it was observed a relationship between leaf fall and dry season.

Upon an ecological point of view the leaf fall uniformity in the mixed stand, provides the best soil protection over the year. 
INTRODUÇÃO

O processo de industrialização em acelerado de senvolvimento nos últimos anos, e a constante preocupação do homem na procura de novas áreas tem provocado uma demanda mui to grande e sempre crescente de produtos florestais, contribuindo para a devastação e extermỉnio das florestas naturais.

Os reflorestamentos que estão sendo realizados não conseguem acompanhar a devastação florestal, alēm de serem executados com espécies alienígenas, especialmente dos gêneros Pinus e Eucalyptus.

As essências florestais nativas vão paulatinamente desaparecendo, constituindo motivo de preocupação entre os pesquisadores, industriais, madeireiros e ecologistas, os quais desejam a continuidade de produção de madeiras de alto valor comercial e a perpetuação das chamadas essências de "ma deira de lei". 
Os estudos florestais sobre as espécies nativas de uma maneira geral, são incipientes e os existentes relacionam-se, principalmente, às características botânicas e dendrológicas.

Pouco se sabe sobre as características silviculturais, o padrão de crescimento e as exigências nutricionais das essências florestais indígenas.

Segundo GARRIDO et alii (1978) a experimentação com essências nativas no Instituto Florestal do Estado de são Paulo iniciou-se na década de 1940, visando estudar, dentre outros aspectos, as caracteristicas silviculturais dessas espécies em povoamentos florestais puros coetâneos.

Com base nos resultados obtidos por vários pe $\underline{\mathbf{s}}$ quisadores do Instituto Florestal, foi instalado o presente experimento que teve por objetivo o estudo de cinco espécies indigenas plantadas em povoamentos puros e misto.

Dentre outras caracteristicas foram observadas: o crescimento dendrométrico, o tipo de ramificação, a susceptibilidade à geada, a capacidade de derrama natural, a forma da árvore e os aspectos fenolögicos.

Este estudo envolveu as seguintes espécies flo restais nativas: 
a) Angico preto - Anadenanthera falcata

(Benth) Brenan;

b) Aroeira - Astronium urundeuva (Er.Al1) Eng;

c) Cambará - Gochnatia polymorpha (Less) Cabr;

d) Ipê-roxo - Tabebuia impetiginosa (Mart.)

Tol;

e) Saguaragi - Colubrina rufa Reiss.

Outro aspecto estudado foi a deposição das folhas das espécies citadas, objetivando avaliar o efeito desses povoamentos florestais sobre a deposição de matéria orgânica.

Os estudos da ciclagem de nutrientes no Brasil estão concentrados principalmente nos gêneros Pinus e Eucalyp tus, não existindo até agora dados quanto ao comportamento das espécies nativas.

Segundo PATRIC e SMITH (1975), o ciclo de nutrientes de uma floresta vem a ser o uso e a reutilização dos elementos minerais do solo pelos vegetais que constituem o ecossistema florestal.

Sabe-se que as espēcies diferem entre si nas suas capacidades de absorção de nutrientes e que os minerais não estão similarmente distribuídos nos tecidos vegetais; co- 
mo resultado, a composição da serapilheira varia consideravel mente de espécie para espécie.

O conhecimento da ciclagem de nutrientes pelas plantas, é, portanto, de vital importância, pois está relacionado com a fertilidade do solo, com a pre venção e correção de possíveis deficiências nutricionais e com o poder de assimilação das espécies utilizadas.

Concluindo, os principais objetivos foram: a) estudar as caracterîsticas sillviculturais das espécies plantą das em povoamentos puros e misto e, b) avaliar a quantidade e o teor de nutrientes nas folhas que se depositaram no solo. 
2. REVISÃO DE LITERATURA

No que se refere à pesquisa e experimentação com essências florestais brasileiras, a literatura nacional 으 ferece escasso material de consulta. De um modo geral o pesquisador florestal brasileiro conhece melhor espécies florestais alienigenas do que as indígenas.

A revisão bibliogräfica será apresentada em vạ rios tópicos de acordo com os objetivos que nortearam o presente trabalho.

2.1 Formação de povoamentos florestais com essências nativas.

A implantação de um determinado tipo de flores ta depende principalmente da finalidade ou dos objetivos propostos. 
Quando os objetivos são econômicos, ou sejam, visam a obtenção de um retorno no menor tempo possível, tem sido dado preferência a povoamentos puros, com essências florestais alienígenas, de rápido crescimento.

A formação de florestas mistas, apesar dos re conhecidos valores ecológicos que elas podem proporcionar, não encontrou até agora, adeptos e simpatizantes que pudessem motivar essa atividade florestal.

Alguns silvicultores registraram a importância e a necessidade de implantação de florestas mistas como ê o caso de PICKEL (1951) que na palestra proferida no Serviço Florestal do Estado de são Paulo, afirmou que a "constituição de maciços florestais mistos deveria ser a principal preocupa ção no reflorestamento nacional" •

VEIGA (1976) tece considerações sobre as vantą gens dos povoamentos mistos sobre os povoamentos puros; afirmando que do ponto de vista biológico e ecológico deve-se dar preferência para a floresta mista.

Para corroborar as afirmações de PICKEL (1951) e VEIGA (1976) são apresentados os trabalhos de DAUBENMIRE (1953), METZ (1954), BISWELL et alii (1966) e MC CLURKIN (1970). Esses autores estudaram por intermédio da serapilhei- 
ra de povoamentos florestais mistos, as implicações práticas advindas das diferentes associações de vegetais por eles pesquisadas. Concluíram que a quantidade, qualidade (composição em nutrientes) e a distribuição da manta florestal concorrem para a melhoria do solo, além de fortes evidências quanto à diminuição do perigo de incêndios, da melhoria da fauna silves tre e da maior penetração no solo das águas das chuvas.

Enfatizando esses aspectos, DAUBENMIRE (1953) sugere a necessidade de se manter uma determinada espécie de baixo valor econômico, porque ela è útil para a manutenção da fertilidade do solo em associação com outras espécies florestais.

Em se tratando da anălise e introspecção de po voamentos mistos, convém ter em mente, conforme FERRI (1974) que há plantas que eliminam no solo, por suas folhas caídas ou por suas raỉzes, substâncias inibidoras do crescimento de outras espécies.

Outro problema que deve ser ponderádo nas asso ciações é quanto ao aspecto de tolerância, pois existem espécíes que exigem luz direta para o seu desenvolvimento, outras só crescem à sombra.

Procurando conciliar os aspectos econômicos e 
biológicos, na implantação de uma floresta, SHAPLAND (1974) recomenda o plantio de florestas mistas de folhosas com coníferas que possam produzir renda mais cedo, diminuindo os custos de implantação e produzindo também madeira de melhor qualidade.

Esse autor, em consonância com FERRI (1974), adverte para as precauções que devem ser tomadas ao se projetar uma floresta mista. Sendo necessário, portanto, ter bons e profundos conhecimentos sobre as espécies utilizadas.

\subsection{Experimentos com essências nativas.}

A pesquisa e experimentação com espécies flom restais nativas apesar da sua importância não tem merecido, por parte dos pesquisadores florestais, a devida atenção. Por isso as informações sobre as essências florestais indỉgenas são bastante raras.

Essa deficiência de informações ê ressaltada por DUBOIS (1970) ao afirmar que o emprego no reflorestamento de espēcies latifoliadas indígenas enfrenta no Brasil duas condições adversas: a) a falta de informações sobre o cresci mento, comportamento fitossanitārio e exigências ecológicas e b) a inexistência de Reservas Florestais de Produção que se-jam manejadas adequadamente. 
O referido autor enfatiza a necessidade de pes quisas com espécies florestais brasileiras, recomendando a criação de um centro de pesquisas cuja finalidade seria estudar o comportamento e crescimento das espécies nativas. Recomenda, também, a constituição de Reservas Florestais de Produ ção as quais deveriam ser manejadas adequadamente. Julga inte ressante o estabelecimento de Reservas de Matas Nativas de Pro teção e de Produção onde os trabalhos de renovação dos recursos florestais se apoiariam no plantio ou na regeneração natu ral.

O Instituto Florestal da Secretaria da Agricul tura e Abastecimento do Estado de São Paulo tem procurado desenvolver pesquisas com essências nativas, enfocando os mais variados aspectos, GARRIDO et alii (1978).

Citam-se por exemplo os trabalhos de GURGEL FI LHO e CASTRO PÁSZTOR (1963), BARROS (1970), GURGEL FILHO e MO RAIS (1972), GURGEL FILHO (1975), NOGUEIRA e SIQUEIRA (1976) e NOGUEIRA (1977) que de uma maneira geral enfocam o estudo dos caracteres silviculturais de quase uma centena de espécies florestais nativas.

GURGEL FILHO e CASTRO PASZTOR (1963) fizeram um estudo de aspectos fenológicos de um grande número de espé cies florestais nativas. Neste trabalho, relacionam além dos 
dados fenológicos ligados às épocas de floração e de frutificação e cor das flores, ainda outros pertinentes ao tipo de frutificação, à arborescência e informaçōes sobre a produção de mudas das espécies estudadas.

GURGEL FILHO (1975) relata os resultados alcan Çados com a pesquisa e a experimentação de essências nativas num perỉodo de mais de vinte anos. Esse pesquisador concluiu que as espécies indígenas apresentam certos comportamentos florestais mais ou menos definidos, em grupos, em função do tipo de ramificação peculiar. Observou também a existência de espécies que apresentam acentuada ramificação monopodial mesmo a pleno sol, constituindo, por conseguinte, fustes bem definidos, como por exemplo: pinheiro brasileiro, o araribá e o pau marfim. Outras essências apresentam ramificação simpodial, não havendo espontaneamente formação de fustes, a não ser em condições especiais de sombra.

BARROS (1970) estudou o espaçamento inicial pa ra aroeira, concluindo que o melhor espaçamento está compreen dido entre $2,00 \times 4,00$ e $2,00 \times 2,00 \mathrm{~m}$, pois foi os que apresentaram os melhores indices de crescimento aos 4,5 anos de $\underline{i}$ dade.

C.P.F.R.C. - PRODEPEF (1976) relata um estudo do comportamento e da sucessão das espécies nativas chamadas 
pioneiras, que se estabelecem com um crescimento rápido, e das dominadas que apresentam dificuldades de implantação, e que tem crescimento lento na idade juveril, mas possuidoras de madeira de alto valor comercial. Esse trabalho está sendo desenvolvido no Centro de Pesquisas Florestais da Região de Cerrado, Brasilia. A pesquisa consiste no plantio de espécies consideradas pioneiras ou de luz em consociação com as espécies dominadas ou de sombra.

Como conclusões preliminares mencionam-se, que o plantio antecipado das espécies pioneiras deu melhores resultados, e, que dentre as espécies de crescimento mais rápido destacou-se o pau-jacaré (Piptadenia comunis) e as que apresentaram melhor forma foram o angico-cangalha (Piptadenia sp), Gonçalo Alves (Astronium fraxinifolium) e ipê (Tabebuia $s p)$.

CARVALHO FILHO E MARQUES (1979) publicaram um relatỏrio técnico de avaliação preliminar, a respeito de sele ção de espécies nativas promissoras para atividades de reflorestamento em função das características silviculturais. Esse trabalho tem como objetivo a comparação mediante experimentação de curta duração, das características silviculturais juve nis, como crescimento, comportamento, exigência de luz e derrama natural de um grande nümero de espécies madeireiras de valor comercial comprovado ou potencial. 
Essa pesquisa ainda em desenvolvimento é muito interessante pois permite a obtenção de dados valiosos em um espaço de tempo relativamente curto.

2.3 Considerações ecológicas sobre o estudo do ciclo de. nutrientes.

O livro "Ecologia Temas e Problemas Brasileiros" de FERRI (1974) tece considerações a respeito da conceituação e designação de eventos ecológicos ocorrentes em um ecossistema florestal.

O autor chama de construção da serapilheira a queda de folhas, frutos, flores, sementes, ramos e mesmo tron cos de ärvores.

Esse material todo constitui o "litter", palavra da língua inglesa, para a qual existem termos equivalentes em português, tais como: folhedo, serapilheira ou ainda manta florestal.

O estudo das características da dinâmica de uma floresta, envolve certos parâmetros que precisam ser definidos como por exemplo: Ecossistema que vem a ser, segundo oDum (1973), "qualquer região natural, que inclua organismos 
vivos e substâncias abióticas interatuando para promover uma troca de matérias entre as partes vivas e não vivas. A parte viva corresponde ao componente denominado biocenose (meio vivo) e a parte não viva ao biótopo (meio físico).

Um ecossistema conforme o mesmo autor, compreende quatro constituintes, a saber:

a) substâncias abióticas: compostos orgânicos e inorgânicos do meio;

b) produtores: organismos autotróficos, na maioria plantas verdes, que são capazes de fabricar alimento a partir das substâncias inorgânicas simples;

c) consumidores: organismos heterotróficos, na maioria animais que ingerem outros organismos ou partículas da matēria orgânica;

d) decompositores: organismos heterotróficos, representados, na maioria, por fungos e bactérias, que decompõem as substâncias complexas dos protoplasmas mortos, absorvem parte dos produtos decompostos e libertam substâncias sim ples e utilizáveis pelos produtores.

Esses quatro constituintes estão em permanente relacionamento fazendo com que os elementos químicos estejam em constante movimentação, indo do ambiente para os organismos e destes novamente para o ambiente. Esse fenômeno é chama do de ciclo de nutrientes. 
PRITCHETT (1976), citando REMEZOV admite dois ciclos de nutrientes no ecossistema florestal:

- ciclo geoquímico ou externo ou aberto que en volve a transferência de elementos minerais dentro e ou fora do ecossistema. As entradas no ecossistema são devidas aos nu trientes do ar, às precipitações, à intemperização das rochas, à fixação biológica do nitrogênio e tambēm à fertilizą ção artificial. As saídas, por outro lado, são representadas pelas perdas, por erosão, lavagens, volatização quando ocorrem incêndios e pela remoção dos nutrientes na exploração flo restal.

O outro ciclo reconhecido por PRITCHETT (1976) denomina-se cíclo biológico ou interno que pode ser subdividi do em ciclo bioquímico (dentro da planta) e ciclo biogeoquími co (solo e planta). Esse ciclo tambëm chamado como ciclo fechado envolve algumas etapas, a saber: absorção, translocação, retenção e restituição de nutrientes por parte da vegetação que constitui o ecossistema.

\subsection{Ciclo de nutrientes.}

Conforme JORDAN e KLINE (1972), o estudo siste mătico do ciclo de nutrientes de um ecossistema ê bastante 
recente. Através desse estudo é possível determinar a quantidade total de um elemento e o teor desse elemento dentro do ciclo, durante um período de tempo, sob certas condições físi cas ou atmosféricas.

PATRIC e SMITH (1975) advertem para a possibilidade de deterioração de um ecossistema florestal, principal mente em florestas de ciclo curto. Ressaltam também que a exploração da madeira em intervalos de tempo relativamente curtos, causa desequilibrio ou déficit na balança dos elementos minerais.

POGGIANI et alii (1979) confirmando as pondera ções anteriores, asseveram que uma floresta formada por essên cias de crescimento rápido, quando cortada em ciclos curtos, poderá acarretar prejuízos nas características físicas e químicas do solo.

WAIDE e SWANK (1975) tecem considerações, ale tando sobre o fato de que a geração atual não deve prosperar às custas da geração futura; isto é, não pode consumir os recursos naturais em prejuízo do futuro. Enfatizam, ainda, que o uso racional desses recursos é muito complexo, devido principalmente a dois aspectos básicos: a) as decisões do manejo florestal são tomadas para atender uma demanda variada, que imposta ao sistema pode mudä-lo catastroficamente; b) o siste 
ma ecológico que seria o objeto das decisões do manejo é complexo e constituído de vários conjuntos de muitas espëcies ha vendo, a lëm disso, uma escassez de informações bảsicas.

Com essas afirmações ressalta-se a importância do estudo da ciclagem dos nutrientes e da estabilidade dos ecossistemas e a suas implicações no manejo florestal.

SPAIN (1975) estudou o papel da biota na decom posição da matêria orgânica em diferentes povoamentos florestais e adverte para a necessidade do estudo conjunto de todos os agentes biöticos envolvidos na ciclagem dos nutrientes.

No dizer de POGGIANI (1976) o ciclo de nutrien tes de uma floresta implantada constitui o painel de controle para uma produção continua e equilibrada, possibilitando a previsão de situações que poderiam ser crîticas a më́dio e a longo prazo, tanto em relação à produtividade como em relação às características do solo que é a fonte dos elementos minerais.

REVERSAT (1976) na Costa do Marfim, fez um estudo comparativo do ciclo de nutrientes de uma floresta natural e de uma floresta implantada e concluiu que as quantidades de elementos minerais recirculados anualmente, pela queda das folhas e pelo efeito da lixiviação são da mesma grandeza 
nos dois ecossistemas.

\subsection{Formação da serapilheira}

A formação da serapilheira ou manta florestal, tem sido estudada exaustivamente nas regiões temperadas. O en foque principal é dado sobre a sua quantidade, a qualidade e a decomposição dentre outros fatores.

ACOSTA (1964) determinou a quantidade de matéria orgânica depositada sobre o solo, enfocando cinco aspectos diferentes, a saber: a) peso de folhas vivas; b) quantida de de folhas caídas; cl decomposição da matéria orgânica; d) deterioração dos detritos orgânicos; e) existência de microor ganismos. Com o estudo desses parâmetros concluiu que na floresta tropical o maior fluxo energético, na cadeia alimentar, ocorre através dos detritos, que se constituem em um importan te componente do solo florestal.

Sabe-se que a decomposição dos detritos, no so lo florestal, depende não só do tipo da floresta, quanto a sua composição arbôrea, como da atividade biológica da microfauna e microflora. A decomposição da matéria orgânica varia de acordo com o tipo de povoamento florestal, com a sua idade, com a composição desse povoamento, com a estação do ano e com alguns fatores climáticos. 
Muitos pesquisadores estudaram a decomposição da matêria orgânica em povoamentos implantados, com uma só es pécie, como se pode observar da análise dos trabalhos de coz2O e RIVEROS (1971) e COZZO (1972) e (1974) que avaliaram as quanti da des médias anuais de matéria orgânica depositada por povoamen tos puros de Eucalyptus camaldulensis $(10.429 \mathrm{~kg} / \mathrm{ha}):$ Pinus canariensis $(7.124 \mathrm{~kg} / \mathrm{ha})$ e Robinia pseudoacacia $(6.580 \mathrm{~kg} /$ /ha), localizados na Argentina.

GESSEL e TURNER (1974) observaram a queda da matéria orgânica em um povoamento puro de Alnus rubra de nove anos de idade, concluindo que a produção média anual foi de $4.220 \mathrm{~kg} / \mathrm{ha}$.

As variações nas quantidades de matérìa orgâni ca encontradas entre os trabalhos citados podem ser explica das tendo em vista que esses trabalhos se referem a espécies diferentes e a situações geogräficas também diferentes.

A formação de serapilheira da Floresta Amazôni ca foi estudada por KLINGE e RODRIGUES (1968): colocaram dez caixas coletoras de matéria orgânica de $1 \mathrm{~m}^{2}$ cada uma, distri buidas em meio hectare, e o material coletado foi separado em folhas, ramos e frutos. A deposição anual observada foi de $7,4 \mathrm{t} / \mathrm{ha}$, sendo que as folhas contribuiram $\operatorname{com} 75,7 \%$ e os ou tros detritos orgânicos com 24,3\% 
LANG (197A) analisando, por dois anos, a dinâmica de matéria orgânica, numa floresta mista de carvalho ame ricano, concluiu que a quantidade anual de folhas caídas ao solo por unidade de área, foi semelhante nos dois anos pesqui sados, as variações que ocorreram foram devidas aos agentes ambientais e biológicos.

Essas variações podem ser consideradas como parte de um modelo normal de um ecossistema dinâmico.

HURD (1971) estudando quatro povoamentos diferentes, desde a idade jovem até a adulta, verificou uma grande variação entre as quantidades de matéria orgânica depositạ da sobre o solo. Houve inclusive variações entre os anos pesquisados. Os povoamentos pesquisados foram os seguintes: a) Alnus-Salix, b) Populus-Picea, c) Picea e d) Tsuga-Picea.

ASHTON (1975) trabalhando em um povoamento natural, cuja espécie dominante era o Eucalyptus regnans, avaliou a quantidade anual de matêria orgânica adicionada à sera pilheira, a velocidade de decomposição da mesma e o seu teor de nutrientes. Esses estudos evidenciaram que a quantidade anual foi de 7,66 t/ha e a máxima deposição ocorreu quando a floresta possuía de 40 a 50 anos de idade.

A variação na quantidade de matéria orgânica 
depositada no solo devido ao estágio de desenvolvimento foi verificada por: THAMES (1962) em povoamentos de Pinus taeda e Pinus echinata e por COZzo e RIVEROS (1971) em um povoamento de Eucalyptus camaldulensis. Esses autores encontraram uma correlação positiva entre as alturas das plantas e as quantidades de matéria orgânica depositada no solo. possível que dentro do mesmo povoamento ocorra uma variação da quantidade de matéria orgânica devido às suas características dendromëtricas.

Os trabalhos de RLINGE e RODRIGUES (1968 a), ARAUJO (1970), COZZO e RIVEROS (1971), COZZO (1972) e (1974) evidenciaram a influência dos agentes climảticos na deposição de matēria orgânica. Apesar de se tratar de pesquisas em ambientes diferentes e de povoamentos florestais também diferen tes, foi observado como ponto em comum uma maior deposição de matéria orgânica no período do ano de menor precipitação.

CARPANEZZI (1980) estudou a deposição de matéria orgânica no solo de uma floresta latifoliada semi-caducifôlia e de uma plantação de Eucalyptus spp na região de LenÇois Paulista, Estado de são Paulo. Esse autor discute exaustivamente a variação da deposição devido à variação sazonal. o eucaliptal teve maior deposição foliar no final da primavera e início do verão, períodos de temperatura e pluviosidade elevadas. A floresta latifoliada apresentou uma deposição fo- 
liar mais intensa nos meses de agosto a novembro.

\subsection{Composição da serapilheira}

Não só a quantidade de matéria orgânica devolvida ao solo é importante para a dinâmica de um ecossistema florestal, como também a qualidade desse material, que é representada pelo teor dos elementos químicos existentes na man ta florestal.

A composição da serapilheira de algumas espécies folhosas e resinosas foi estudada por TARRANT et alii (1951). Os resultados obtidos, por esses autores, demonstraram a influência do ambiente no teor de nutrientes das mantas florestais pesquisadas.

Segundo esses autores, deve-se ter cautela para usar o teor de nutrientes da serapilheira, para estimar o estado nutricional da floresta. Isto é devido aos värios fatores envolvidos, tais como ambiente, principalmente solo e épo ca do ano, dentre outros.

KIINGE e RODRIGUES (1968b) quantificaram O CON teủdo de nutrientes na matéria orgânica, depositada anualmente sobre o solo de uma floresta de Terra Firme da Amazônia. 
Os elementos pesquisados e os seus respectivos valores, em $\mathrm{Kg} / \mathrm{ha} / \mathrm{ano}$, são os que se seguem: 2,2 de $\mathrm{P} ; 12,7$ de $\mathrm{K} ; 5,0$ de $\mathrm{Na} ; 18,4$ de $\mathrm{Ca}$ e 12,6 de $\mathrm{Mg}$.

Esses autores concluiram que na manta vegetal da área pesquisada, o retorno anual de nutrientes é muito inferior a de outras florestas tropicais. Quanto às percentagens de cinzas e de nutrientes na serapilheira, a floresta amazônica é também pobre. Essa pobreza em nutrientes deve estar relacionada aos baixos níveis de elementos minerais existentes no solo.

No tocante à composição da serapilheira convếm relatar o trabalho desenvolvido por WEBB et alii (1969). Esses pesquisadores coletaram amostras de serapilheira deposita da mensalmente em duas florestas naturais da Austrália de caracteristicas fisionômicas semelhantes, porém em regiōes distintas. Os resultados observados demonstraram que apesar de ter havido variação na quantidade de matéria orgânica depositada sobre o solo, não houve diferenças marcantes nas concentrações dos elementos minerais analisados.

Esses fatos levaram os autores a aventarem a hipótese de que o teor de nutrientes da serapilheira independe do posicionamento geográfico e da composição das florestas desde que elas tenham estruturas semelhantes. 
2.7 Efeitos da Floresta sobre as condições edäficas.

E sabido que as florestas promovem uma transio cação de nutrientes das camadas mais profundas do solo para a superficie. Essa translocação ocorre da seguinte maneira: absorção pelo sistema radicular da vegetação, translocação interna nas plantas e restituição ao solo pela deposição das folhas, frutos, sementes, galhos e atë troncos.

Segundo SPURR e BURTON (1973) a nutrição mineral da floresta é exercida pela intemperização do material de origem que é a rocha e pela mineralização do nitrogênio atmos Eêrico. Porém a maior deposição de nutrientes sobre a camada superficial do solo é dada pela decomposição da serapilheira. Essa deposição é efetuada pela comunidade florestal constitur da de plantas arbóreas, arbustivas e herbäceas pela macro e micro fauna.

A velocidade de decomposição da manta florestal varia grandemente dependendo de värios fatores, principal mente do clima da região.

Nas florestas tropicais e em algumas temperadas hả pouca ou nenhuma acumulação de matéria orgânica, devido à răpida decomposição. 
Acúmulos pesados ocorrem em florestas de coniferas de vărios climas, devido às condições desfavoráveis aí existentes para a decomposição.

quando a floresta está em clímax, as perdas por lavagem são compensadas pelas entradas através da mineralização do solo, da fixação biológíca e dos elementos contí dos na água da chuva.

A deposição da matéria orgânica no solo nas florestas exerce um papel importante nas características edáficas. A Tabela 1 apresenta as quantidades de minerais restituídos anualmente ao solo por várias formações vegetais de re giões temperadas e tropicais.

Da Tabela 1 visualiza-se que as folhosas devol vem maiores quantidades de Ca e Mg do que as coníferas. Em re lação ao elemento $\underline{P}$ percebe-se que em quase todos os locais do Brasil, a devolução é semelhante para todas as espécies pesquisadas, notando-se porém uma maior devolução ocorrida nas matas naturais latifoliadas de Lençois Paulista. Aliás es sa vegetação foi a que depositou ao solo maior quantidade de matériäa orgânica e também maiores quantidades de nutrientes que as demais formações vegetais. 

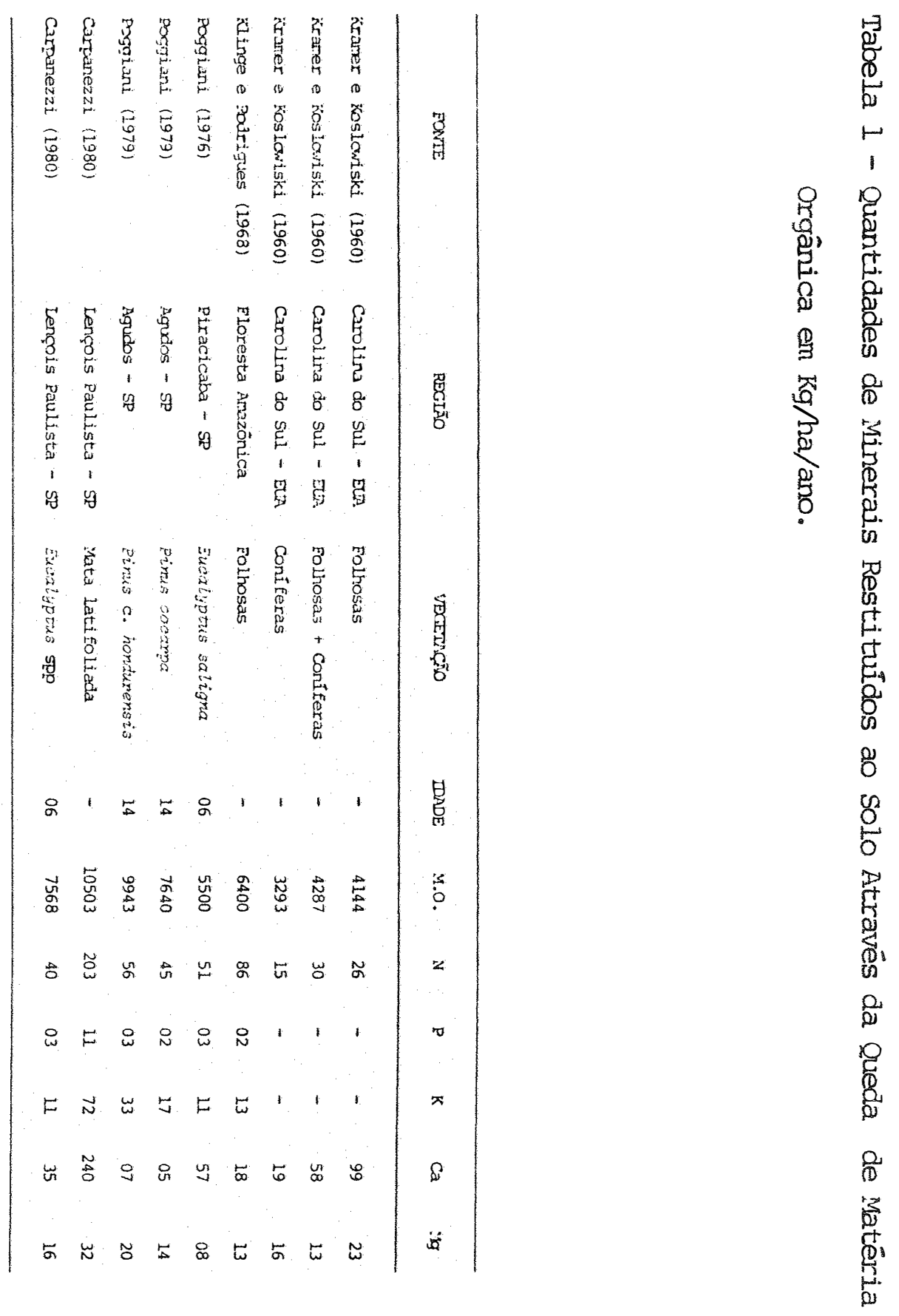
OVINGTON citado por KRAMER e KOSLOWISKI (1960) observou que num mesmo solo, as folhas de um grupo de folho sas continham maior porcentagem de $N, P, K, M g$ do que as foThas de um grupo de coniferas. Estas foram superiores em $C$, Na e Mg não havendo diferença consistente com respeito a $\mathrm{Ca}$, $\mathrm{Fe}$ e $\mathrm{Si} \mathrm{O}_{2}$.

BARROS e BRANDI (1975) desenvolveram um trabatho em Viçosa, Minas Gerals, no qual compararam a eficiência do anda-assu (Joanesia princips), ipê-preto (Zeyheria tubercu losa) e Pinus elliottii, com o capim gordura (Milinis minutiflora), na recuperação de solos desgastados. As espécies florestals apresentavam a ldade de 8 anos e o espaçamento era de $2 \times 2 \mathrm{~m}$. Eles pesquisaram os teores de $\mathrm{P}-\mathrm{K}-\mathrm{Ca}-\mathrm{Mg}-\mathrm{Al}$, matēria orgânica e pH. Os resultados obtidos por esses pesquisadores permitiram as seguintes conclusões:

a) houve superioridade das espécies florestais sobre o capim gordura na recuperação do solo. O capim foi superior às essências florestais no que se refere ao teor de po tẩssio nos $20 \mathrm{~cm}$ superiores do solo:

b) das espécies florestais, o ipê-preto mostrou-se superior às demais sob todos os aspectos, exceto quan to ao teor de $\mathrm{Mg}$, em que houve ligeira supremacia do Pinus e iottii.

c) no cômputo geral, as duas folhosas mostraram-se superiores à conif fera. 
Em geral as coníferas aumentam a acidez da superficie do solo mais do que as folhosas, porém individualmen te há uma grande variação entre as espécies no que diz respe to a esse efeito.

$\bar{A}$ vista do que foi relatado neste capitulo, po de-se afirmar que há uma grande variação nas quantidades de nutrientes dos ciclos geoquímico e biológico, dentro de um ecossistema florestal e as transferências cíclicas são respon sáveis pela manutenção da produtividade dos solos florestais.

Essas afirmações obrigam o silvicultor a ter melhor conhecimento da ciclagem de nutrientes, pois esses estão intimamente relacionados com os programas de manejo e de fertilização florestal.

2.8 Variações encontradas na me todologia

2.8 .1 Caracteres silviculturais.

o estudo dos caracteres silviculturais e fenolögicos das essências florestais brasileiras tem sido feito a partir de plantios artificiais em vários espaçamentos.

Essa assertiva está baseada nos trabalhos desenvolvidos por BARROS (1970), GURGEI FILHO (1975) e NOGUEIRA 
e SIQUEIRA (1976). Esses autores estudaram o comportamento de quase uma centena de espécies florestais brasileiras, crescen do em diferentes espaçamentos, visando observar, principalmen te, o aspecto derrama que é um dos mais sérios problemas no reflorestamento com essências indigenas.

Também é possível estudar os caracteres silviculturais em plantios homogêneos e heterogêneos conforme se depreende do exame das obras de GURGEL FILHO e MORAIS (1972), C.P.F.R.C. - PRODEPEF (1976), NOGUEIRA (1977), CARVALHO FILHO e MARQUES (1979) e GURGEL FILHO et alii (1978).

Basicamente o estudo das características silvi culturais consiste no plantio da espécie em questão, e o acom panhamento do seu crescimento é feito através de mensurações anuais, do diâmetro, altura, do câlculo volumētrico e de observações sobre a forma da árvore, sobre a derrama, tipo de ramificação, dentre outros parâmetros.

2.8.2 Avaliação da deposição de matēria orgânica

A avaliação da deposição de matéria orgânica tem sido motivo de preocupação dos ecologistas e silvicultores, razão pela qual se encontram diversas pesquisas e experí mentações sobre o assunto. 
Apesar da existência de vários trabalhos, observou-se uma grande disparidade entre as metodologias aplica das.

S'egundo KORNÁS (1970) a matéria orgânica depositada no solo durante um determinado período de tempo e sobre uma determinada ärea de um ecossistema pode ser expressa em peso por unidade de área, ou seja, em $\mathrm{Kg} / \mathrm{ha} / \mathrm{ano}$.

O material colhido deve ser seco a temperaturas que variam de $85-105^{\circ} \mathrm{C}$, e a anälise química feita por métodos tradicionalmente conhecidos para que os resultados ob tidos possam ser comparados com os de outros pesquisadores.

A coleta da deposição da matéria orgânica no solo é feita por meio de caixas de madeira ou recipientes de plástico, cuja forma pode ser redonda, quadrada ou retangular.

Este autor recomenda como ideal para coleta, uma caixa de $1 \mathrm{~m}^{2}$ de área e 25 a 30 caixas por hectare devendo-se efetuar coletas mensais num periodo nunca inferior a 12 meses.

A área dessas caixas coletoras também é variável, como se observa no trabalho de ZAVITKOSVSKI e NEWTON 
(1971) que coletaram em caixa de $0,05 \mathrm{~m}^{2}$. GARG e VYAS (1975) usaram um recipiente quadrado de $0,25 \mathrm{~m}^{2}$ de área. WEBB et alii (1969) e RIZZO et alii (1971) estudaram a deposição de matëria orgânica através de uma caixa de $1 \mathrm{~m}^{2}$ de área. Da literatura pesquisada pode-se destacar o trabalho de cozzo e RIVEROS (1971), pois esses autores usaram áreas de coleta da ordem de $1,54 \mathrm{~m}^{2}$.

Existem autores que basearam os seus estudos em apenas uma caixa coletora de $1 \mathrm{~m}^{2}$ de superficie. Outros simplesmente não definiram a metolodogia aplicada.

Outras informações sobre a metodologia a ser usada na avaliação da deposição de matéria orgânica podem ser obtidas em CARPANEZZI (1980). Este autor discute com detalhes os seguintes aspectos: local de amostragem, adequação ou precisão da amostragem, número e disposição das parcelas, forma e tamanho das parcelas e frequência das coletas. 
3. MATERIAL E MÉTODOS

3.1 Material

3.1.1 Localização e topografia

O experimento foi instalado na Estação Experimental de Assis, município de Assis, cujas coordenadas geográficas são: $22^{\circ} 35^{\prime}$ latitude sul e $50^{\circ} 25^{\prime}$ longitude oeste de Greenwhich.

A Estação Experimental de Assis ocupa uma ārea de 1.815 ha, de relevo normal, cujas cotas altitudinais estão entre 520 a $580 \mathrm{~m}$ e no local do experimento a cota é de $544 \mathrm{~m}$ acima do nîvel do mar.

\section{1 .2 Clima}

Pela carta climātica do Estado de são Paulo or ganizada por BLANCO e GODOY (1967), com base no sistema de Köppen, o clima da região de Assis é do tipo Cwa, em que a temperatura média do mês mais quente é a $23^{\circ} \mathrm{C}$ e a do mês 
mais frio é 1 inferior a $18^{\circ} \mathrm{C}$. De acordo com essa classificação, a estação seca ocorre entre os meses de abril a setembro, sendo julho e agosto os meses em que atinge maior intensidade.

São apresentados na Tabela 2 , os dados termo pluviométricos coletados durante o ano de 1977 no local do ex perimento.

A medida das precipitações foi feita por meio de um pluviômetro do tipo "Paulista" e as temperaturas por um tesmômetro de máxima e mínima que estão junto ao escritório đa estação experimental, distando $200 \mathrm{~m}$ do local do experimen to.

\section{1 .3 solo}

De acordo com FREITAS e SILVEIRA (1977), O sO Lo do local do experimento é um Latosol Vermelho Escuro Distrófico de textura média, muito profundo, horizonte A fraco, horizonte B latossólico, rico em sesquióxidos e de coloração vermelho escura, muito poroso, bastante permeável, bem drenado, ácido e de baixa fertilidade.

A análise química do solo coletado em quinze pontos da área da estação experimental realizada em 1970, apresentou os seguintes resultados constantes da Tabela 3. 
Tabela 2. Dados Termopluviométricos Observados na Estação Experimental de Assis durante o Ano de 1977.

\begin{tabular}{|c|c|c|c|}
\hline MESES & $\underset{\text { (mm) }}{\text { Precipitação }}$ & $\underset{\left(O_{C}\right)}{\text { Tempax. }}$ & $\underset{\left({ }^{\circ}\right)}{\text { Temp }}$ \\
\hline Jane i ro & 356,0 & 33,0 & 21,0 \\
\hline Fevereiro & 80,0 & 34,4 & 20,8 \\
\hline Março & 115,3 & 35,0 & 20,9 \\
\hline Abril & 40,8 & 28,8 & 16,4 \\
\hline Maio & 38,5 & 27,2 & 14,4 \\
\hline Junho & 62,0 & 24,9 & 13,7 \\
\hline Julho & 16,0 & 29,7 & 16,6 \\
\hline Agosto & 9,0 & 29,9 & 14,5 \\
\hline Setembro & 62,0 & 30,0 & 16,0 \\
\hline Outubro & 52,5 & 32,9 & 18,0 \\
\hline Novembro & 199,7 & 31,0 & 18,6 \\
\hline Dezembro & 291,0 & 30,4 & 18,7 \\
\hline TOTAL & $1.322,8$ & & \\
\hline MEDIA & & 30,6 & 17,5 \\
\hline
\end{tabular}


Tabela 3. Anälise Quimica do Solo da Estação Experimental de Assis, Efetuada em 1970, pelo Instituto Agronômico de Campinas, da Secretaria de Agricultura e Abastecimento.

\begin{tabular}{|c|c|c|c|c|c|c|}
\hline & & & emg & 100 & mI de T.E.S.A & \\
\hline Amostras & $\mathrm{pH}$ & $8 \mathrm{C}$ & $\mathrm{PO}_{4}^{---}$ & $\mathrm{K}^{+}$ & $\mathrm{Ca}^{++}+\mathrm{Mg}^{++}$ & $\mathrm{Al}+++$ \\
\hline 01 & 5,4 & 1,30 & 0,02 & 0,05 & 0,40 & 0,50 \\
\hline 02 & 4,5 & 1,55 & 0,02 & 0,05 & 0,30 & 1,50 \\
\hline 03 & 4,9 & 1.70 & 0,04 & 0.05 & 0,30 & 1,40 \\
\hline 04 & 4,9 & 1,40 & 0,03 & 0,07 & 0,50 & 1,00 \\
\hline 05 & 4,5 & 1,25 & 0,02 & 0,05 & 0,20 & 1,30 \\
\hline 06 & 5,0 & 1,50 & 0,03 & 0,05 & 0,30 & 1,40 \\
\hline 07 & 5,1 & 1,80 & 0,02 & 0,06 & 0,20 & 1,40 \\
\hline 08 & 4,7 & 1,40 & 0,02 & 0,05 & 0,20 & 1,10 \\
\hline 09 & 4.7 & 1,30 & 0.02 & 0,05 & 0,30 & 0,90 \\
\hline 10 & 4,8 & 1,50 & 0,04 & 0,04 & 0,20 & 1,60 \\
\hline 11 & 5,3 & 1,30 & 0,03 & 0,04 & 0.20 & 0,90 \\
\hline 12 & 4.9 & 1,10 & 0,02 & 0,04 & 0,20 & 0,90 \\
\hline 13 & 5,1 & 1,10 & 0,02 & 0,04 & 0,20 & 0,90 \\
\hline 14 & 4,8 & 1,90 & 0,03 & 0,04 & 0,20 & 1,50 \\
\hline 15 & 4.9 & 1,10 & 0,02 & 0,04 & 0,20 & 0,80 \\
\hline$x$ & 4,9 & 1,4 & 0,02 & 0,05 & 0,26 & 1,14 \\
\hline
\end{tabular}




\subsubsection{Diaurama climático}

A classificação climätica anresentada define o macro clima da reaião de Assis. Sequndo WALTER (1979) o clima de um determinado local ou estação pode ser claramente caracterizado por meio de uma representação aráfica chamada Diaqrama climático, que contëm as informações bäsicas para o ecoloaista.

O diacrama climático ecolōgico consiste em se colocar os meses do ano no eixo das abscissas, iniciando-se em julho para o hemisfério sul, de modo que a estação quente doano apareca semore no centro do gráfico. No eixo dasordenadas dis tribuem-se as temperaturas médias mensais e as precipitações médias mensais, obtendo-se desta forma, com a união dos pontos a curva da temperatura e a curva da precipitação.

O diagrama climātico fornece ainda outras informações, tais como: a ocorrência, duração e a intensidade da estação chuvosa; a estação seca; a duração e a severidade do inverno local e a possibilidade de geadas.

Na Figura 1 o clima da Estação Experimental de Assis é representado na forma de um diagrama climático. Nesta figura pode-se observar que não chega a caracterizar-se uma estação muito seca, pois nos meses de baixa precipitação, as temperaturas registradas também são baixas. Percebe-se também que no periodo de outubro a maio ocorrem chuvas mensais acima de $100 \mathrm{~mm}$. 


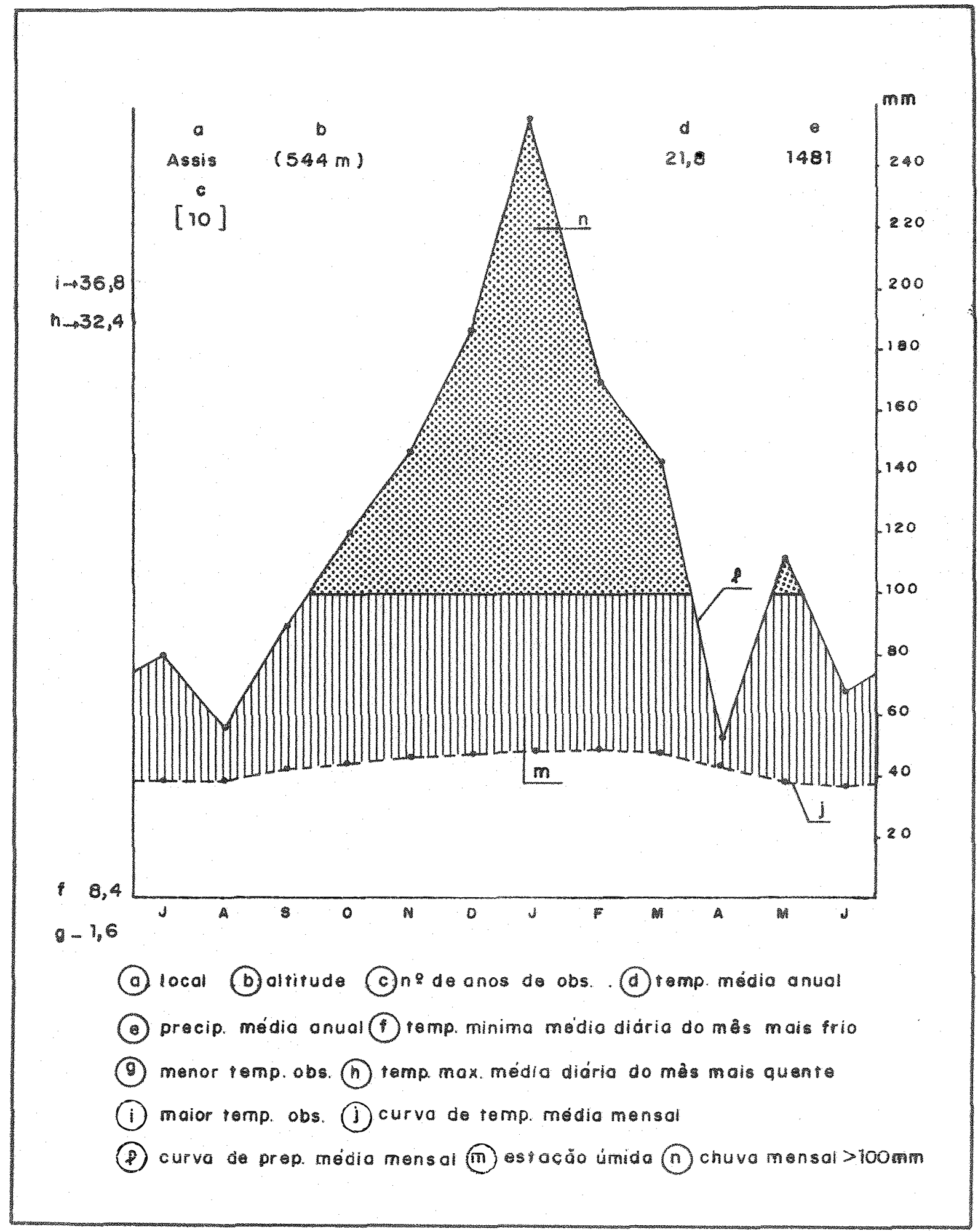

Figura 1. Diagrama Climătico da Estação Experimental de Assis. 
3.1 .5 vegetação primitiva

Na ëpoca da instalação do presente experimento a vegetação existente era a grama batatais lPaspalum notatum). Entretanto a área da estação experimental possui como vegetação natural ou primitiva, aquela descrita por FERRI (1974) como Cerrado.

O cerrado dessa região caracteriza-se por apre sentar árvores cujas alturas variam de 6 a $10 \mathrm{~m}$ é uma formação vegetal pouco densa, com predominância das árvores sobre os arbustos e gramineas, todavia não chega a se constituir um cerradão.

\subsubsection{Essências florestais usadas}

As essências florestais, objeto dessa pesquisa e experimentação, são de ocorrência natural do Estado de são Paulo, pertencendo a 05 (cinco) familias botânicas a saber:

$$
\text { Angico - Anadenanthera falcata (Benth) Brenan. }
$$

Leguminosae;

Aroeira - Astronium urundeuva Engl. Anacardia-

ceae;

$$
\text { Cambará - Gochnatia polymorpha (Less) Cabr.Com }
$$

positae;

$$
\text { Ipê-roxo - Tabebuia impetiginosa (Mart) Tol. }
$$

Bignoniaceae: 
Saguaragi - Colubrina rufa Reiss Rhamnaceae.

\subsubsection{Descrição das espécies}

A descrição que serä apresentada, a seguir está baseada nos trabalhos de PRIMO (1968): CABRERA (1971); RIZ ZINI (1971); HERINGER e FERREIRA (1973); HUECK (1973); RIZZINI e NORS (1976) e RIZZINI (1977)。

a) O angico-preto ou angico-do-cerrado, An $\underline{a}$ denanthera falcata (Benth) Brenan, da familia Leguminosae, sub-familia Mimosoidae, é árvore de grande porte na mata e de pequeno porte no cerrado. Possui casca dura, espessa, e fundą mente gretada, muito comum nos cerrados de são Paulo e Paraná, mais rara nas matas secas e cerrados mineiros. A madeira é pe sada, dura e resistente à deterioraçãa, dentre outros usos destacam-se construções rurais, moirões de cerca e lenha.

b) A aroeira - Astronium urundeuva (Fr. All)

Engl. é uma árvore da famỉlia Anacardiacea, pequena no cerrado e na caatinga, grande na floresta pluvial. Ocorre nas zonas do sertão baiano, penetrando pela caatinga de pluviosidade baixa, atinge Pernambuco, Alagoas, Sergipe, indo de maneira descontinua até o extremo norte da Argentina, de um lado, a até a Bolívia de outro. Aparece em terrenos desde a planície até $900 \mathrm{~m}$ de altitude. Esta espécie è frequente na região de cerrado, surgindo nos afloramentos calcáreos, alcançando nesses solos, grandes dimensões. 
A árvore pode atingir até $30 \mathrm{~m}$ de altura, nas florestas pluviais, e, $15 \mathrm{~m}$ de altura e de 0,30 a $0,60 \mathrm{~m}$ de diâmetro nas matas ciliares e caatingas. Nas formações flores tais está associada, dentre outras espécies, à Piptadenia spp; Choxizia speciosa, Tabebuia impetiginosa e Hymenaea stilbocar pa. Ela pode ser cultivada, com resultados econômicos, até mesmo no cerrado típico, desde que inicialmente se façam cala gens. Perde a folhagem no estio, floresce no início da primavera e dentro de curto tempo os frutos estão maduros e quando isso acontece, as árvores se cobrem de folhagem avermelhada. c) o cambará, tambëm chamado candeia, da família botânica Compositae, Gochnatia polymorpha (Less) Cabr., é uma árvore que dificilmente alcança altura superior a 8 metros, sendo encontrada geralmente nas bordas da mata, em condições de farta luminosidade, razão pela qual é raramente encontrada na mata alta e fechada. Prefere solos bem drenados, ou inundáveis por curto período. E considerada uma das precur soras mais resistentes na invasão de campos, em condições de solo bem drenado. Poucas vezes seu tronco é reto, à semelhança do angico è quase sempre inclinado.

Sua folhagem é de cor verde-clara. As folhas simples tem cor esbranquiçada na parte ventral. As folhas são persistentes, porém sua massa foliar sofre uma pequena diminuição durante os meses de inverno. As flores, pequenas, bran cas aparecem nos meses de verão (novembro a janeiro) na ponta 
dos ramos do ano.

O tronco, normalmente curto, chega a $25-30 \mathrm{~cm}$ de diâmetro, com fendas longitudinais pouco profundas.

A madeira do cambará tem pouco alburno quando em idade avançada, apresentando farto cerne, muito durável, intensamente utilizada para moirões de cerca.

A ocorrência do cambará vai desde a Bahia, atẻ - Rio Grande do Sul, indo para oeste até o Paraguai.

d) O ipê-roxo, Tabebuia impetiginosa (Mart) Tol. é da familia Bignoniaceae, de grande porte, podendo alcançar até $30 \mathrm{~m}$ de altura e $30 \mathrm{~cm}$ de diâmetro. Os folỉolos em nümero de cinco, são desiguais, coriáceos oblongos ou oval-oblongos, de base arredondada. As folhas são caducas, caindo no periodo do florescimento que ocorre entre julho e setembro.

A distribuição geográfica do ipê-roxo abarca a região que vai do Piauí e Ceará até São Paulo. Em Minas Gerais passa das matas para os pastos, comoárvore solitária. 음 casional no cerrado e na caatinga.

A madeira é duríssima, pesada e indefinidamente durável; é empregada em construções pesadas, estruturas ex 
ternas, civis e navais.

e) o saguaragi, ou sobrasil, Colubrina rufa Reiss., ārvore da família Rhamnaceae, é de porte médio, elegante, de uns 10-15 $\mathrm{m}$ de altura por 40-60 cm de diâmetro; ë comum em todo o interior do Estado de são Paulo em terras de mata, quer sejam arenitos férteis, solos rasos ou profundos e não ocorrendo em cerrado e cerradão.

o florescimento se verifica em fevereiro-abril e a frutificação de julho a outubro.

Apresenta fuste retilíneo, cilíndrico, com altura útil em torno de $10 \mathrm{~m}$. As folhas, em geral, são alternas, ou sub-opostas e oblongas. Tem como características marcantes a derrama e cicatrização fácil, mesmo em espaçamentos largos.

A madeira do saguaragi é de cor bege-rosada-es cura, uniforme de superfície lustrosa e lisa. E dura, pesada e extremamente resistente à deterioração. Sua madeira è semelhante à do pau-brasil.

Dentre as inümeras utilidades que a madeira do saguaragi tem, destacam-se: construção naval, estacas, pontes moirões, postes e dormentes. Essa madeira é de durabilidade semelhante à da aroeira. 
Sua ocorrência natural se dá na Floresta Atlân tica, desde o Rio de Janeiro até o Rio Grande do Sul, ocorren do, também, no sul do Mato Grosso ào sul e de Goiás.

\subsubsection{Instalação do experimento}

As mudas foram produzidas no viveiro da estação experimental, em embalagem do tipo Torrão Paulista; a par tir de sementes colhidas de árvores existentes no município de Assis, com exceção das sementes de aroeira que vieram da região de Oswaldo Cruz (SP).

Durante os seis meses que as mudas estiveram no viveiro, os tratos culturais requeridos e executados se li mitaram à limpeza e às regas diárias, porque não houve incidência nem de pragas nem de moléstias.

O preparo do solo constou de uma aração profun da e uma gradagem, não exigindo maiores cuidados, porque o so lo era vegetado pela grama batatais Paspalum notatum.

O plantio das mudas foi executado no dia $01 / 12$ /1970, quando o solo se encontrava umidecido.

Durante o ano de 1977, foi feita a coleta das folhas que cairam no solo. Usaram-se para isso, caixas de ma- 
deira, de forma quadrada de $1 \mathrm{~m}$ de lado. Essas caixas estavam apoiadas em suportes que as deixavam a $0,50 \mathrm{~m}$ do solo.

Foram colocadas 14 caixas de $1 \mathrm{~m}^{2}$ em uma parce la de cada tratamento, sendo, portanto, a relação de amostragem de $14 \mathrm{~m}^{2}$ para $192 \mathrm{~m}^{2}$ (área da parcela) ou 729 caixas cole toras por hectare.

\subsection{Métodos}

O delineamento estatístico adotado foi o de Blocos ao Acaso, com seis tratamentos e quatro repetições, a saber:

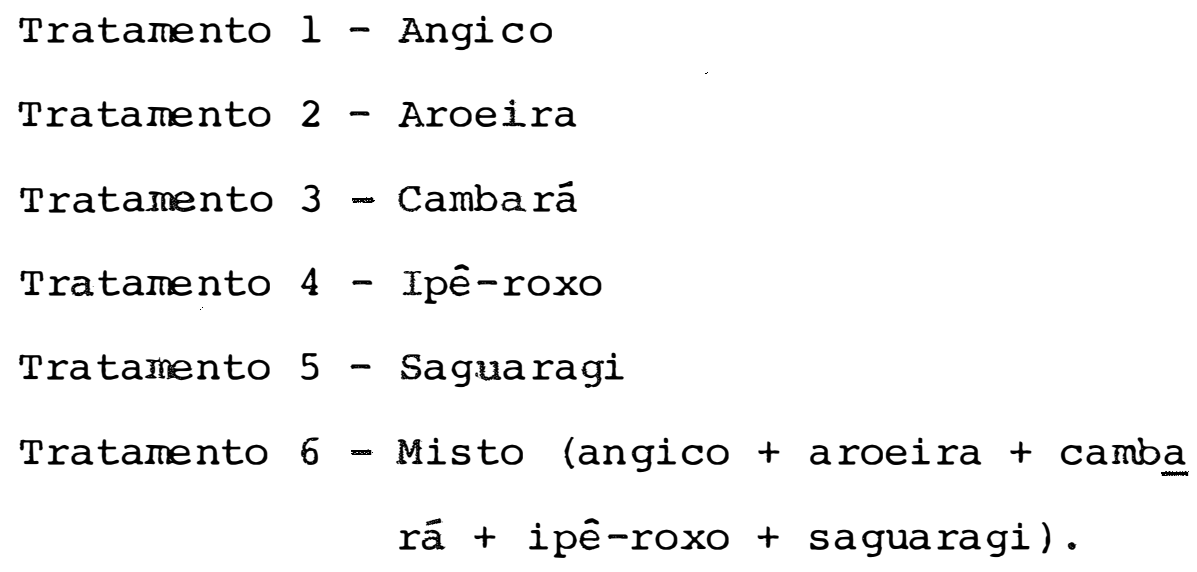

Os tratamentos de nümeros 1 a 5 constituiram os povoamentos puros, e o de nümero 6 , o povoamento misto.

No tratamento nümero 6 , as espécies foram plan 
tadas ao acaso, através de um único sorteio para as quatro parcelas.

Plantaramrse, em cada uma das parcelas, 48 mudas no espaçamento quadrado de $2 \mathrm{~m} \times 2 \mathrm{~m}$, perfazendo uma área ütil de $192 \mathrm{~m}^{2}$.

Adotaranrse, como medida de segurança, 2 bordaduras internas e duas bordaduras externas, nas quais plantou-se angico.

Somando-se a área útil das 24 parcelas e a ārea das bordaduras, a superfície total do experimento foi de $9.900 \mathrm{~m}^{2}$.

A metodologia empregada na coleta das folhas está de acordo com KORNÁs (1970), como consta no capítulo de revisão bibliográfica.

Como o propósito dessa coleta visava apenas o material folhas, no momento da retirada das caixas coleitoras foram eliminados os ramos, frutos, sementes, botões florais, dentre outros componentes orgânicos.

O material colhido destas caixas, recebeu uma secagem prévia ao sol, seguida de secagem em estufa a $85^{\circ} \mathrm{C}$ atē peso constante. A seguir, foi pesado e analisado para cál 
culo dos teores de nitrogênio, fósforo, potássio, cálcio e magnésio, pelo Departamento de Química da Escola superior de Agricultura "Luiz de Queiroz", de acordo com as instruções contidas em SARRUGE e HAAG (1974).

3.3 Roteiro da pesquisa e experimentação

O desenvolvimento da pesquisa e experimentação obedeceu a um planejamento previamente elaborado, o qual cons tou suscintamente dos seguintes tópicos:

3.3.1 Obtenção das sementes.

3.3.2 Preparo das mudas.

3.3.3 Instalação do experimento, compreendendo o sorteio das parcelas, a marcação das linhas de plantio, o coveamento e o plantio.

3.3.4 Tratos culturais: capinas, desbrota e derrama.

3.3.5 Dendrometria: mensurações anuais, da altura, através do Relascópio de Bitterlich e do diâmetro, através da suta metálica. As medidas foram efetuadas sempre no mês de julho.

3.3.6 Observação periódica dos caracteres silviculturais e fenológicos.

3.3.7 Cálculos dendrométricos, representados pelas médias aritméticas e taxas anuais de acréscimo. 
3.3.8 Execução do desbaste no momento adequado (1978).

3.3.9 Elaboração da Ficha Dendrométrica Para Controle do Desbaste.

3.3.10 Coleta mensal das folhas depositadas no solo, observação da precipitação e da temperatura no ano de 1977 .

3.3.11 Preparo, secagem e pesagem das folhas.

3.3.12 Anålise química das folhas coletadas mensalmente para determinação dos elementos: nitrogênio, fósfo ro, patássio, cálcio e ganésio. 
4. RESUltados

Com o intuito de propiciar maior clareza, a exposição dos resultados obtidos será feita em três tópicos sendo que o primeiro reflete a evolução do crescimento dos po voamentos florestais, o segundo, a quantidade de matéria orgâa nica e o terceiro a concentração de nutrientes devolvidos ao solo através da queda das folhas, durante o ano de 1977.

4.1 Crescimento

A evolução do crescimento das espécies em estü do foi acompanhada pelas mensurações anuais de altura e diâme tro. 
Nas Tabelas 4 e 5 , estão apresentadas as mëdias das alturas e dos diâmetros das ảrvores e os seus respec tivos intervalos de confiança.

Tabela 4. Médias e Intervalos de Confiança (5\%) dos Diâmetros das Árvores dos Povoamentos Puros e do Povoamento Misto $(\mathrm{cm})$.

\begin{tabular}{lrlcccc}
\hline Pov. & $\begin{array}{c}\text { Angico } \\
\text { x.I.C. }\end{array}$ & $\begin{array}{c}\text { Aroeira } \\
\text { X.I.C. }\end{array}$ & $\begin{array}{c}\text { Cambara } \\
\text { x.I.C. }\end{array}$ & $\begin{array}{c}\text { Ipe-roxo Saguaragi } \\
\text { X.I.C. }\end{array}$ & $\begin{array}{c}\text { Misto } \\
\text { x.I.C. }\end{array}$ & x.I.C. \\
\hline 1973 & $4,9 \pm 1,3$ & $2,2 \pm 0,5$ & $2,5 \pm 0,3$ & $2,3 \pm 0,1$ & $4,0 \pm 1,4$ & $3,5 \pm 1,0$ \\
1974 & $6,5 \pm 1,8$ & $3,5 \pm 0,8$ & $4,2 \pm 0,9$ & $3,2 \pm 0,2$ & $5,5 \pm 0,8$ & $4,9 \pm 1,4$ \\
$1975 *$ & $7,8 \pm 1,6$ & $4,6 \pm 0,9$ & $6,0 \pm 0,7$ & $3,6 \pm 0,3$ & $6,1 \pm 0,8$ & $6,1 \pm 1,1$ \\
1976 & $8,9 \pm 1,2$ & $5,3 \pm 1,2$ & $7,0 \pm 0,6$ & $4,1 \pm 0,6$ & $2,1 \pm 0,3$ & $6,4 \pm 1,3$ \\
1977 & $9,8 \pm 1,3$ & $5,8 \pm 1,4$ & $8,3 \pm 1,8$ & $4,5 \pm 0,7$ & $3,7 \pm 0,3$ & $7,3 \pm 0,7$ \\
1978 & $10,5 \pm 1,2$ & $6,6 \pm 1,3$ & $8,6 \pm 0,6$ & $4,7 \pm 0,4$ & $5,0 \pm 0,2$ & $8,0 \pm 0,4$ \\
1979 & $13,1 \pm 1,5$ & $8,5 \pm 1,2$ & $9,9 \pm 1,2$ & $5,6 \pm 0,5$ & $6,0 \pm 0,4$ & $9,7 \pm 0,8$ \\
1980 & $14,2 \pm 1,4$ & $9,3 \pm 1,3$ & $10,8 \pm 1,5$ & $6,2 \pm 0,8$ & $6,6 \pm 0,5$ & $10,7 \pm 0,9$ \\
\hline
\end{tabular}

(*) Ano de ocorrência de uma forte geada que afetou a parte aérea das plantas de ipê-roxo e de saguaragi. 
Tabela 5. Médias e Intervalos de Confiança (5\%) das Alturas (m) das Árvores dos Povoamentos Puros e do Povoamen to Misto.

\begin{tabular}{|c|c|c|c|c|c|c|}
\hline Pov. & $\begin{array}{l}\text { Angico } \\
\bar{x} \cdot I . C .\end{array}$ & $\begin{array}{l}\text { Aroeira } \\
\bar{x} . I . C .\end{array}$ & $\begin{array}{l}\text { Cambarā } \\
\bar{x} \cdot I . C .\end{array}$ & $\begin{array}{l}\text { Ipê-roxo } \\
\bar{x} . I . C .\end{array}$ & $\begin{array}{c}\text { Saguaragi } \\
\bar{x} \cdot I . C .\end{array}$ & $\begin{array}{l}\text { Misto } \\
\bar{x} . I . C .\end{array}$ \\
\hline 1972 & $2,9 \pm 0,8$ & $2,0 \pm 0,4$ & $1,8 \pm 0,2$ & $1,3 \pm 0,1$ & $1,6 \pm 0,7$ & $2,2 \pm 0,3$ \\
\hline 1973 & $4,8 \pm 1,4$ & $3,0 \pm 0,5$ & $3,0 \pm 0,5$ & $2,6 \pm 0,4$ & $4,0 \pm 1,1$ & $3,6 \pm 0,9$ \\
\hline 1974 & $5,2 \pm 1,3$ & $3,5 \pm 0,6$ & $4,0 \pm 0,6$ & $2,9 \pm 0,2$ & $4,8 \pm 1,0$ & $4,4 \pm 0,9$ \\
\hline $1975 *$ & $6,0 \pm 1,5$ & $4,5 \pm 0,8$ & $4,6 \pm 0,5$ & $3,2 \pm 0,2$ & $5,8 \pm 1,0$ & $5,0 \pm 1,0$ \\
\hline 1976 & $6,4 \pm 1,5$ & $5,0 \pm 1,0$ & $5,3 \pm 0,5$ & $3,1 \pm 0,3$ & $2,3 \pm 0,3$ & $4,8 \pm 0,9$ \\
\hline 1977 & $7,2 \pm 1,2$ & $5,6 \pm 1,1$ & $5,9 \pm 0,7$ & $3,7 \pm 0,1$ & $3,7 \pm 0,3$ & $5,8 \pm 0,5$ \\
\hline 1978 & $8,0 \pm 0,8$ & $6,4 \pm 1,0$ & $6,1 \pm 0,6$ & $4,0 \pm 0,4$ & $5,2 \pm 0,2$ & $6,5 \pm 0,4$ \\
\hline 1979 & $9,5 \pm 0,8$ & $7,6 \pm 1,0$ & $6,7 \pm 1,8$ & $4,9 \pm 0,6$ & $6,1 \pm 0,5$ & $7,4 \pm 0,5$ \\
\hline 1980 & $9,9 \pm 0,8$ & $8,0 \pm 1,0$ & $7,0 \pm 2,0$ & $5,3 \pm 0,5$ & $6,8 \pm 0,4$ & $8,0 \pm 0,6$ \\
\hline
\end{tabular}

Nestas tabelas estä evidenciado o melhor comportamento do angico desde as primeiras mensurações tanto em altura como em diâmetro. As Figuras 2 e 3 mostram esse cresci mento na forma de gráfico.

(*) Ano de ocorrência de uma forte geada que afetou a parte aérea das plantas de ìpê-roxo e de saguaragi. 




Figura 2. Crescimento em Diâmetro dos Povoamentos Puros e do Misto. 


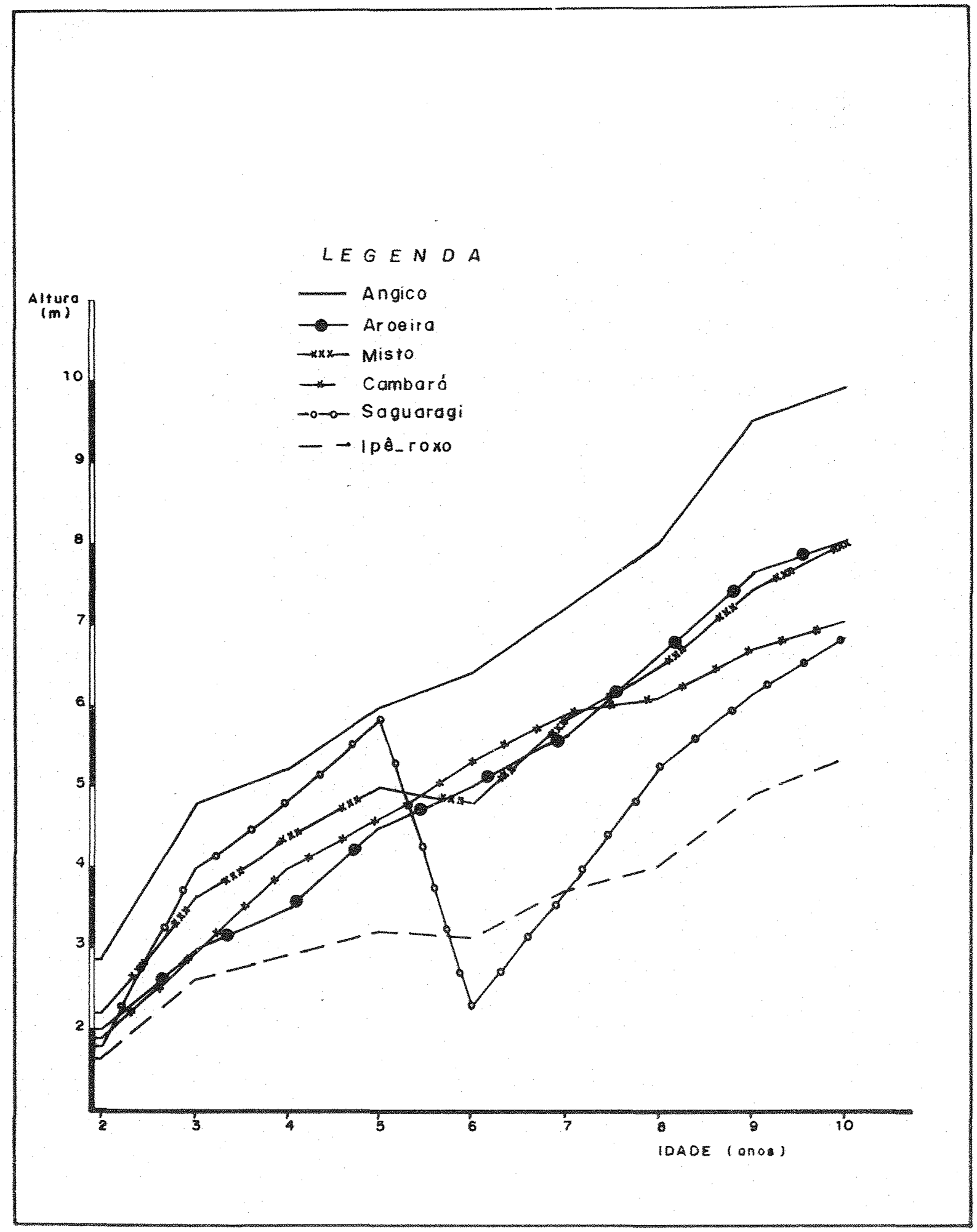

Figura 3. Crescimento em Altura dos Povoamentos Puros e do Misto. 
o povoamento de saguaragi, em 1975, foi afetado severamente por uma geada, que matou a parte aērea das ārvores dessa espécie e também de algumas plantas de ipê-roxo. Os troncos foram cortados rente ao sollo o que facilitou a bro tação de todas as touças. Este evento explica a interrupção da progressão referente aos valores de crescimento apresentados nas Tabelas 4 e 5 e Figuras 2 e 3.

No periodo que antecedeu a geada o crescimento em altura do saguaragi foi semelhante ao do angico.

Conforme observações efetuadas em 1980, o cres cimento em altura dos povoamentos está na seguinte ordem decrescente: angico, aroeira, misto, cambará, saguaragi e ipê-roxo. Para o crescimento em diâmetro: angico, cambará, misto, aroeira, saguaragi e ipê-roxo.

A silvicultura moderna propicia ao técnico flo restal métodos e princípios matemáticos que avaliam a velocidade de crescimento das ärvores florestais. Dentre os métodos existentes lançou-se mão da Taxa de Acréscimo, que é calculada anualmente, dando informações de quanto cresce cada povoamento florestal em estudo.

A partir das médias dos diâmetros foram calculadas para cada um dos povoamentos puros e misto, as taxas de 
acrēscimo que são mostradas na Tabela 6 .

Tabela 6. Taxas Anuais de Acrëscimo Dadas em Porcentagem.

\begin{tabular}{lccccccc}
\hline $\begin{array}{l}\text { Periodos } \\
\text { Povoamentos }\end{array}$ & $73 / 74$ & $74 / 75$ & $75 / 76$ & $76 / 77$ & $77 / 78$ & $78 / 79$ & $79 / 80$ \\
\hline Angico & 28 & 18 & 13 & 10 & 07 & 22 & 08 \\
Aroeira & 45 & 27 & 14 & 09 & 11 & 25 & 13 \\
Cambará & 51 & 35 & 14 & 18 & 04 & 14 & 08 \\
Saguaragi & 32 & 11 & - & 55 & 30 & 18 & 10 \\
Ipê-roxo & 33 & 12 & 16 & 10 & 05 & 16 & 09 \\
Misto & 33 & 22 & 02 & 15 & 09 & 18 & 10 \\
\hline
\end{tabular}

A taxa de acréscimo, è calculada a partir das médìas dos diâmetros das árvores, conforme a fórmula:

$$
t=\frac{\text { DAP ATUAL - DAP ANTERIOR }}{\frac{\text { DAP ATUAL + DAP ANTERIOR }}{2}} \times 100
$$

onde $t=$ Taxa de acréscimo, em porcentagem e DAP = média dos diâmetros à altura do peito.

Pela visualização da Tabela 6 fica evidente o crescimento que as espēcies florestais apresentaram inicialmente, expressado pelas altas taxas de acrëscimo. Esse desenvolvimento rápido decresceu nos períodos de 1976/1977 e 1977/1978, quando a competição se tornou mais acentuada. 
Adotou-se como parâmetro indicativo do momento do desbaste quando as taxas de acréscimo estavam em tôrno de $10 \%$, sendo este realizado em julho de 1978.

E interessante salientar mais uma vez, a ocor rência de geada no ano de 1975, que impossibilitou o cálculo da taxa de acréscimo para o povoamento puro de saguaragi e afetou a taxa do ipê-roxo, referente ao crescimento entre 1975 e 1976 ,

A Tabela 7 denominada Ficha Dendrométrica para Controle de Desbaste retrata detalhadamente a situação dos povoamentos florestais de angico, aroeira, cambará, ipê-roxo, saguaragi e do povoamento misto, por ocasião da execução do desbaste em julho de 1978 .

Os valores calculados para a área basal, volume e nümero de plantas são relativos a um hectare e os valores de altura e diâmetro refletem a média aritmética das parcelas de cada povoamento florestal.

Estes valores, foram obtidos através dos métodos e das fórmulas que a dasometria consagrou e que constam do trabalho de VEIGA (1976). 




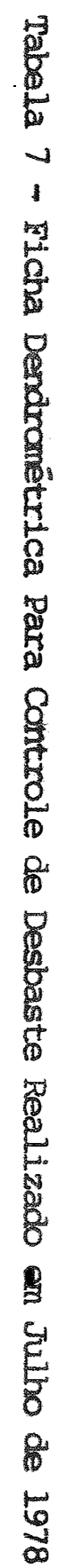


A Tabela 8 apresenta a média das alturas e dos diâmetros aos 9 anos, notando-se uma pequena preponderância do crescimento de todas as espëcies no taihão misto. Atravês do teste $t$ foi feita a comparação estatística dos dados, a qual não acusou diferenças significativas a não ser para os valores de altura da aroeira ao nivel de 5 \%

Tabela 8. Comparação pelo Teste "t", Entre as Médias dos Diâmetros e das Alturas das Årvores plantadas em Povoa mento Misto e em Povoamentos Puros, aos Nove Anos de Idade.

\begin{tabular}{|c|c|c|c|c|c|c|}
\hline & \multicolumn{2}{|c|}{$\mathrm{DAP} \quad(\mathrm{cm})$} & \multirow{2}{*}{$\begin{array}{l}\text { Valor de } \\
\text { "t" }\end{array}$} & \multicolumn{2}{|c|}{ ALTURA (m) } & \multirow{2}{*}{ Valor ${ }_{\text {"t" }} \mathrm{de}$} \\
\hline & Misto & Puro & & Misto & Puro & \\
\hline Angico & 14,0 & 13,1 & $0,91 \mathrm{n} . \mathrm{s}$. & 9,26 & 9,50 & $0.45 \mathrm{n} . \mathrm{s}$. \\
\hline Aroeira & 9,6 & 8,4 & $1,21 \mathrm{n.s}$. & 8,42 & 7,59 & $2,58 *$ \\
\hline Cambarä & 11,7 & 9,9 & $1,52 \mathrm{n} . \mathrm{s}$. & 7,52 & 6,73 & $1,23 \mathrm{n} . \mathrm{s}$. \\
\hline Ipê-roxo & 5,5 & 5,5 & $0,08 \mathrm{n} . \mathrm{s}$. & 5,11 & 4,93 & $0,40 \mathrm{n.s}$. \\
\hline Saguaragi & 6,9 & 6,0 & $1,40 \mathrm{n.s}$ & 5,87 & 6,13 & $0,49 \mathrm{n.s}$. \\
\hline
\end{tabular}

4.2 Deposição das folhas.

No ano de 1977, através da coleta mensal das folhas, foi possivel determinar as quantidades depositadas no solo pelos povoamentos puros de angico, aroeira, cambará e 
ipê-roxo, e do povoamento misto.

Apresentam-se na Tabela 9 , as quantidades mensais, a quantidade total anual e a média mensal, em quilos por hectare para cada tipo de povoamento florestal.

Tabela 9. Matẻria Sêca em $\mathrm{kg} / \mathrm{ha}$ Depositada no Solo Através das Folhas dos Povoamentos Puros e Misto.

\begin{tabular}{|c|c|c|c|c|c|}
\hline & \multicolumn{4}{|c|}{ POVOAMENTIOS PUROS } & \multirow{2}{*}{$\begin{array}{l}\text { POVOAMENTO } \\
\text { MISTO }\end{array}$} \\
\hline & Angico & Aroeira & Cambará & Ipē-roxo & \\
\hline Janeiro & 215,46 & 41,69 & 445,81 & 38,55 & 103,99 \\
\hline Fevereiro & 661,52 & 93,72 & 366,77 & 257,64 & 238,31 \\
\hline Março & 516,61 & 112,25 & 313,44 & 203,95 & 202,29 \\
\hline $\mathrm{Ab} \times 11$ & 328,68 & 99,98 & 268,48 & 126,19 & 226,82 \\
\hline Maio & 287,79 & 619,31 & 179,95 & 69,91 & 190,69 \\
\hline Junho & 184,50 & 962,80 & 233,20 & 58,70 & 279,00 \\
\hline Julho & 333,80 & 126,20 & 227,50 & 65,40 & 219,40 \\
\hline Agosto & 661,90 & 98,90 & 431,40 & 62,40 & 313,60 \\
\hline Setembro & 625,10 & 10,20 & 739,50 & 32,50 & 309,00 \\
\hline Outubro & 267,70 & 4,80 & 780,70 & 13,80 & 229,80 \\
\hline Novemb ro & 57,20 & 56,50 & 55,80 & 43,90 & 140,08 \\
\hline Dezembro & 240,60 & 70.27 & 708,55 & 6,81 & 163,24 \\
\hline $\begin{array}{l}\text { TOTAI } \\
\text { Anual }\end{array}$ & $4.380,86$ & $2.296,62$ & $4.751,10$ & 979,75 & $2.616,22$ \\
\hline $\begin{array}{l}\text { MEDDIA } \\
\text { Mensal }\end{array}$ & 365,07 & 191,38 & 395,93 & 81,65 & 218,03 \\
\hline
\end{tabular}


Dentre os povoamentos puros destacaram-se o de cambarä e o de angico, seguidos dos poroamentos de aroeira e de ipê-roxo. Como aconteceu no crescimento das ärvores, tam bëm na deposição de folhas o povoamento misto ocupou uma posi ção intermediäria entre os quatro povoamentos puros.

A distribuição anual da queda das folhas das essências em estudo, pode ser visualizada e analisada, nas Figuras de nümeros 4 a 8 . Nessas figuras apresentam-se os resultados das pesagens das folhas coletadas, durante o ano de 1977.

o exame da Figura 4, que mostra a deposição mensal de folhas do povoamento puro de angico, evidencia a existência de dois picos, um nos meses de fevereiro e março e o outro nos meses de agosto e setembro, sendo que a menor que da ocorreu no mês de novembro.

Verificou-se tambëm, uma maior queda de folha no periodo mais seco do ano (julho, agosto, setembro, outubro ). 




Figura 4. Matéria Seca Em Kg/ha Depositada No Solo Através Das Folhas Do Povoamento Puro Do Angico. 
A Figura 5 retrata a deposição mensal de folhas pelo povoamento de aroeira. Percebe-se claramente a maior queda das folhas no mês de junho, quando caíram 962,80 quilos por hectare. A menor deposição ocorreu nos meses de se tembro e outubro, quando foram registrados valores da ordem de 10,20 e 4,80 quilos por hectare, respectivamente.

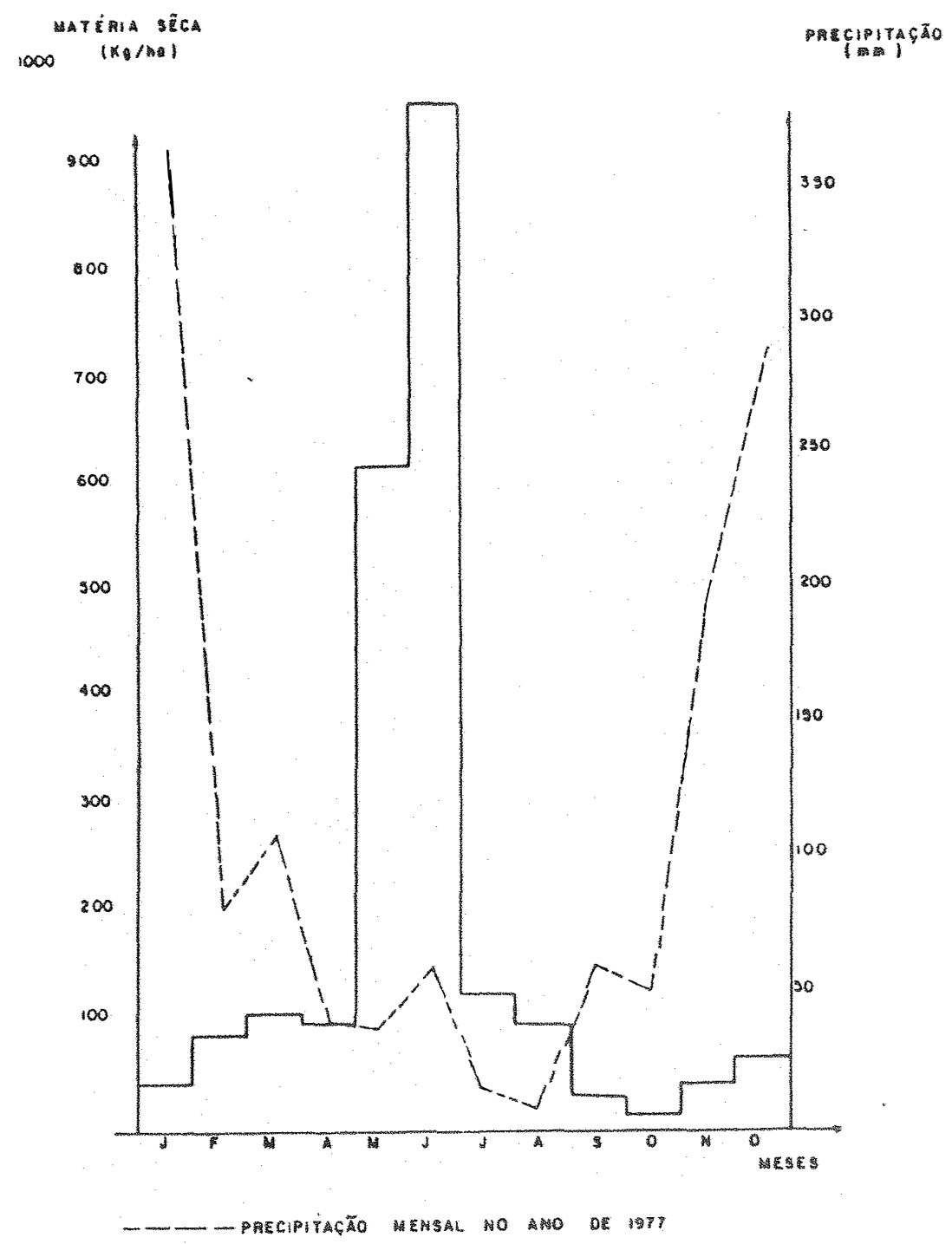

Figura 5. Matēria Seca Em Kg/Ha Depositada No Solo Atravës Das Folhas Do Povoamento Puro Da Aroeira. 
o povoamento puro de cambará destacou-se pela maior deposição de folhas, e também pela existência de vảrios periodos de grande queda de folhas, conforme mostra a Fi gura 6. Contudo nota-se uma maiox intensidade na queda de foThas nos meses de setembro e outubro.

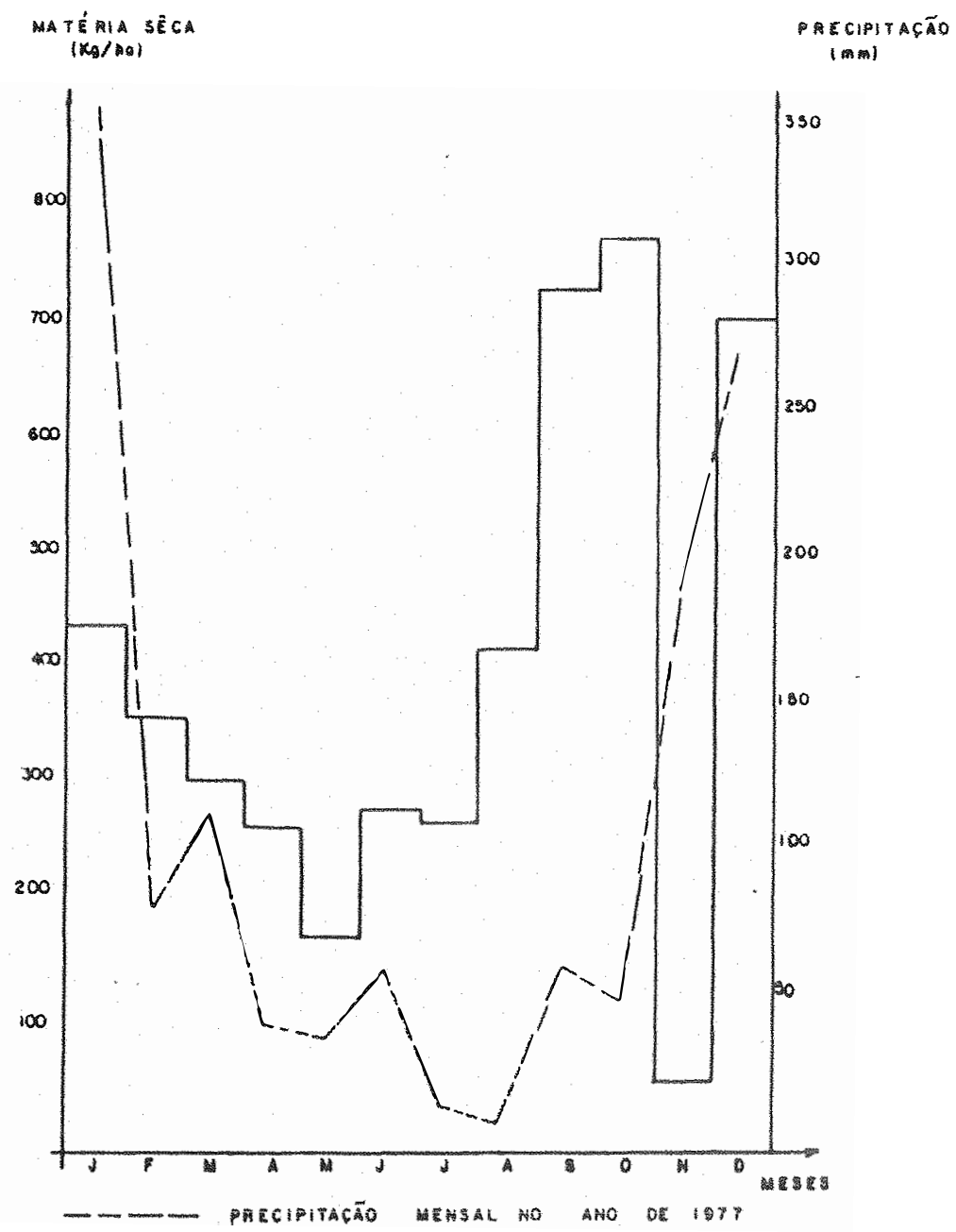

Figura 6. Matêria Seca, Em Kg/Ha Depositada No Solo Através Das Folhas Do Povoamento Puro Do Cambará. 
Com relação ao povoamento de ipê-roxo, o destą que que se pode observar no gráfico da Figura 7 ë o decréscimo constante da deposição de folhas a partir do mês de fevereiro. Este povoamento teve a menor deposiçäo não atingindo $1.000 \mathrm{Kg} / \mathrm{ha}$.

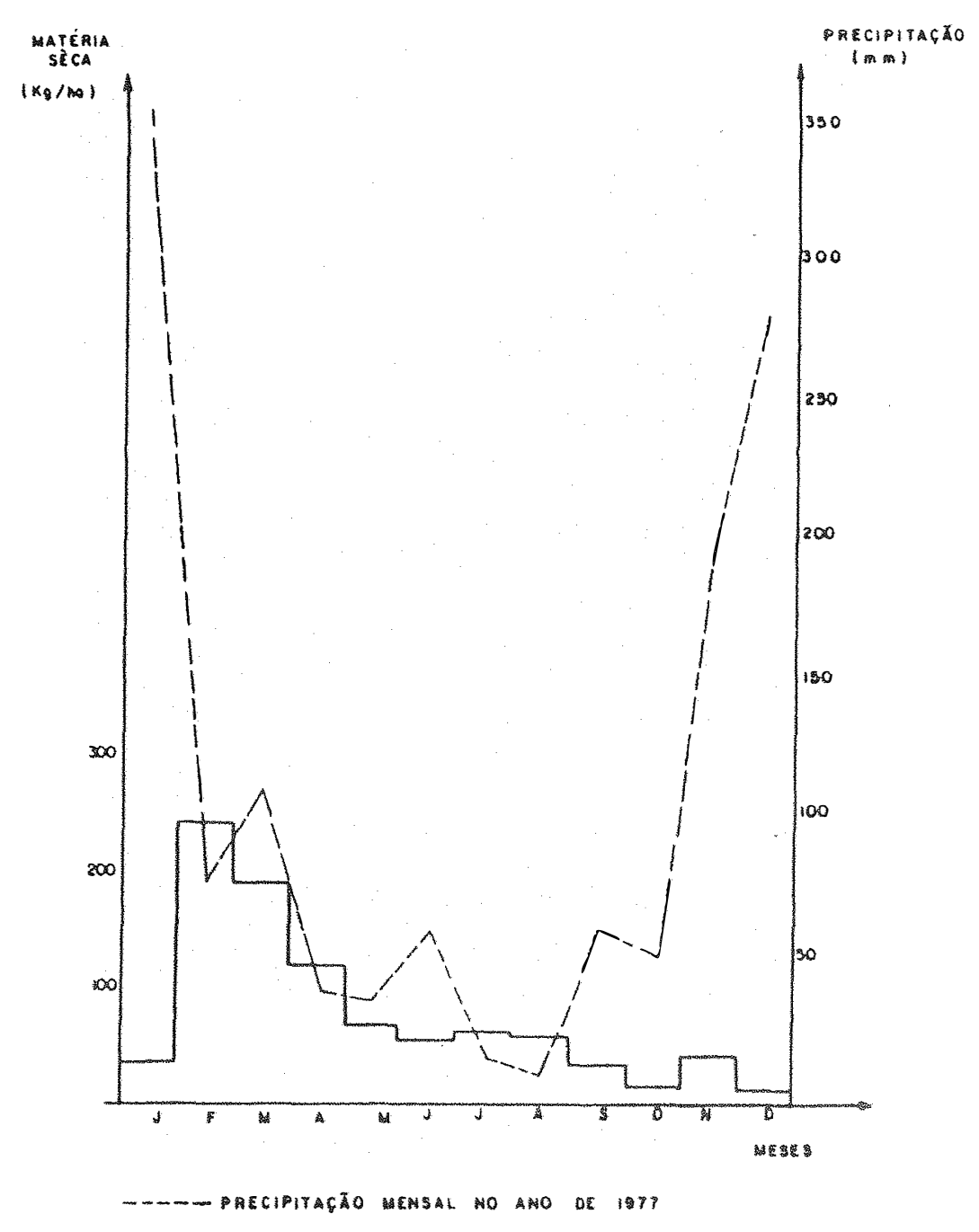

Figura 7. Matéria Seca, Em Kg/HA Depositada No Solo Atravës Das Folhas Do Povoamento Puro Do Ipê-roxo. 
o povoamento misto, constituido por todas as espécies florestais em estudo, no que diz respeito à deposição de folhas, não apresentou flutuação muito acentuada. Houve um máximo da ordem de 313,60 quilos, verificado em agosto para um minimo de 103,99 quilos por hectare ocorrido em janei ro (Figura 8).

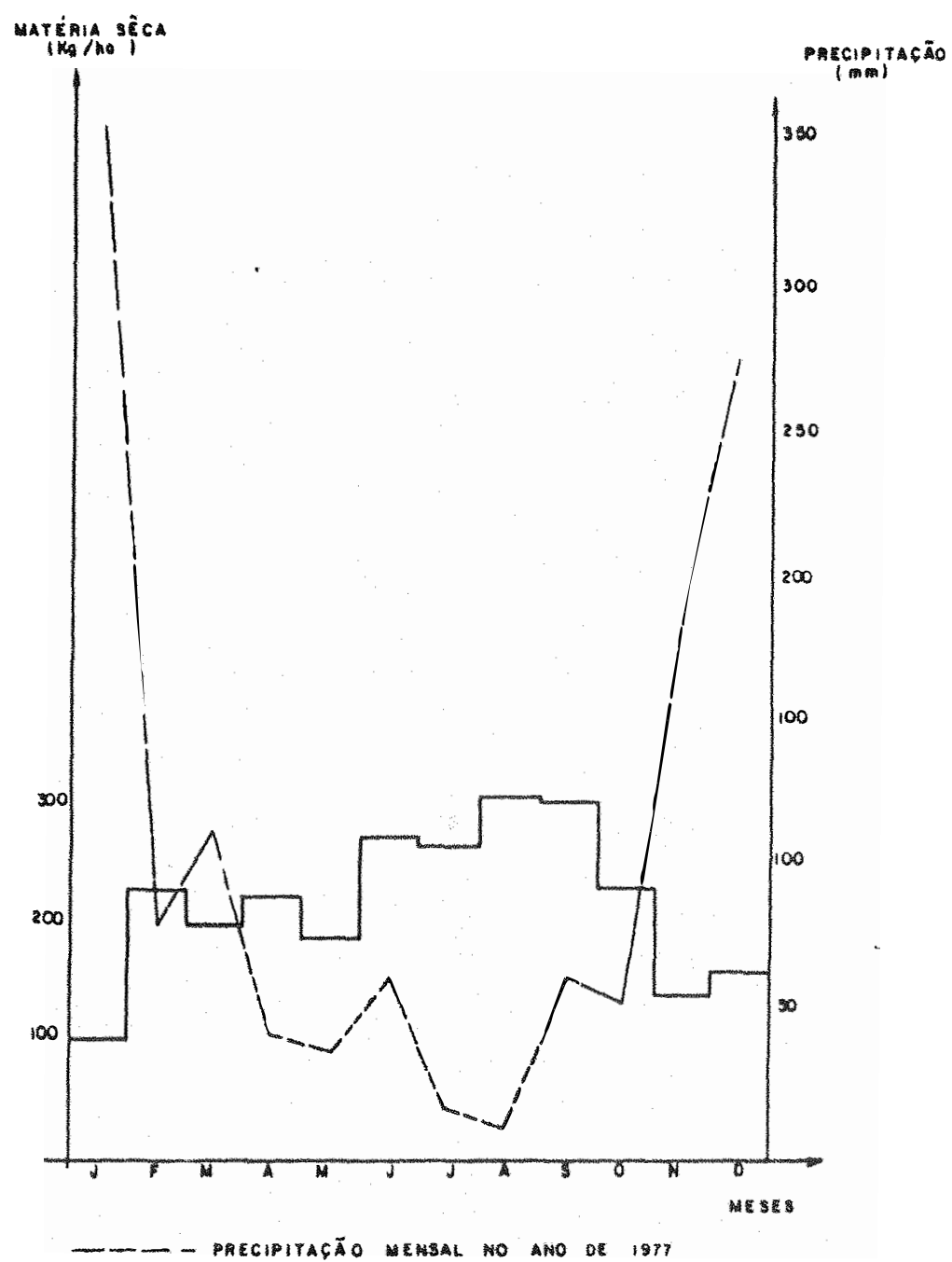

Figura 8. Matëria Seca, Em Kg/HA Depositada No Solo Através Das Folhas Do Povoamento Misto. 
Quando se compara a deposição de folhas dos po voamentos puros e do misto verifica-se que a maior deposição foi obtida, em média, nos povoamentos puros, como se observa na Tabela 10, que mostra as médias da produção de folhas dos povoamentos puros e a produção do povoamento misto durante os doze meses do ano de 1977.

Tabela 10. Deposição Mensal $\mathrm{Em} \mathrm{Kg/Ha} \mathrm{De} \mathrm{Folhas} \mathrm{Dos} \mathrm{Povoamen-}$ tos Puros (média) e do Povoamento Misto no Ano de 1977.

\begin{tabular}{lrr}
\hline Meses & \multicolumn{2}{c}{ Povoamentos } \\
& Puros (média) & Misto \\
\hline Janeiro & 185,38 & 103,99 \\
Fevereiro & 344,91 & 238,31 \\
Março & 286,56 & 202,29 \\
Abril & 205,83 & 226,82 \\
Maio & 289,24 & 190,69 \\
Junho & 359,80 & 279,00 \\
Julho & 188,23 & 219,40 \\
Agosto & 313,65 & 313,60 \\
Setembro & 351,83 & 309,00 \\
Outubro & 266,75 & 229,80 \\
Novembro & 53,35 & 140,08 \\
Dezembro & 256,56 & 163,24 \\
\hline TOTAL ANUAL & $3.102,06$ & $2,616,24$ \\
MEDIAS & 258,51 & 218,02 \\
\hline
\end{tabular}


4.3 Variação dos elementos químicos das folhas decíduas nos povoamentos florestais

A composição química das folhas coletadas foi avaliada pela análise das mesmas verificando-se os teores de nitrogênio, fósforo, potássio, cálcio e magnésio.

Como a coleta de folhas foi mensal, procedeu-se também à análise quỉmica mensal, cujos teores são apresen tados nas Tabelas 11 e 12 .

A Tabela 11 mostra as flutuações na concentração de nutrientes das folhas decỉduas durante o ano de 1977. Já a Tabela 12 apresenta o teor médio dos elementos químicos nas folhas depositadas no solo pelos povoamentos florestais em estudo.

A Tabela 13 mostra a devolução anual de nutrientes em $\mathrm{Kg} / \mathrm{ha}$ pelas folhas decíduas dos povoamentos florestais de angico, aroeira, ipê-roxo e do povoamento misto. 
Tabela 11. Variação Mensal da Concentração de Nutrientes das Folhas Decíduas dos Povoamentos Puros e do Misto. Expressa em Porcentagem.

\begin{tabular}{|c|c|c|c|c|c|c|c|c|c|c|c|c|}
\hline \multicolumn{13}{|c|}{ Angion } \\
\hline & Jan. & Fev. & Mar. & $A b r$. & Mai. & Jun. & Jut. & Ago. & set. & out. & Nov. & Dez. \\
\hline N & 2,42 & 2,24 & 2,18 & 1,92 & 2,02 & 1,86 & 1,90 & 1,18 & 1,68 & 2,27 & 2,58 & 2,55 \\
\hline $\mathrm{p}$ & 0,07 & 0,05 & 0,06 & 0,08 & 0,05 & 0,09 & 0,08 & 0,07 & 0,05 & 0,08 & 0,11 & 0,08 \\
\hline$k$ & 0,21 & 0,51 & 0,33 & 0,14 & 0,18 & 0,28 & 0,26 & 0,59 & 0,15 & 0,32 & 0,29 & 0,42 \\
\hline $\mathrm{Ca}$ & 0,58 & 0,68 & 0,67 & 0,63 & 0,73 & 0,68 & 0,78 & 1,04 & 0,72 & 0,67 & 0,39 & 0,50 \\
\hline ikg & 0.13 & 0,20 & 0,14 & 0,12 & 0,13 & 0,14 & 0,17 & 0,26 & 0,09 & 0,12 & 0,15 & 0,17 \\
\hline
\end{tabular}

Arceira

\begin{tabular}{lllllllllllll}
\hline$N$ & 1,97 & 1,55 & 1,37 & 1,57 & 1,40 & 1,29 & 1,65 & 1,44 & 1,69 & 2,85 & 2,33 & 1,53 \\
$\mathrm{P}$ & 0,07 & 0,05 & 0,05 & 0,07 & 0,05 & 0,07 & 0,06 & 0,09 & 0,05 & 0,13 & 0,11 & 0,06 \\
$\mathrm{~K}$ & 0,36 & 0,85 & 0,77 & 0,55 & 0,59 & 0,56 & 0,51 & 0,51 & 0,26 & 1,00 & 0,80 & 0,41 \\
$\mathrm{Ca}$ & 0,73 & 0,78 & 0,76 & 0,85 & 1,17 & 1,16 & 0,80 & 0,93 & 0,75 & 0,56 & 0,56 & 0,69 \\
$\mathrm{Mg}$ & 0,25 & 0,27 & 0,21 & 0,21 & 0,24 & 0,31 & 0,24 & 0,27 & 0,13 & 0,26 & 0,30 & 0,25 \\
\hline
\end{tabular}


Continuação da Tabela 11.

\begin{tabular}{|c|c|c|c|c|c|c|c|c|c|c|c|c|}
\hline & \multicolumn{12}{|c|}{ Canibarä } \\
\hline & Jan. & Eev. & Mar. & Abr. & Mai. & Jun. & Jul. & Ago. & set. & out. & Nov. & Dez. \\
\hline $\mathrm{N}$ & 1,30 & 1,43 & 1,26 & 1,33 & 1,22 & 1,09 & 1,13 & 1,05 & 1,18 & 1,12 & 0,98 & 1,25 \\
\hline$p$ & 0,03 & 0,03 & 0,04 & 0,06 & 0,05 & 0,10 & 0,08 & 0,07 & 0,05 & 0,03 & 0,03 & 0,04 \\
\hline$k$ & 0,95 & 1,98 & 1,59 & 1,36 & 1,15 & 1,84 & 1,63 & 1,65 & 1,15 & 0,59 & 0,91 & 1,25 \\
\hline$c a$ & 0,83 & 0,78 & 0,64 & 0,53 & 0,52 & 0,60 & 0,45 & 0,46 & 0,56 & 0,55 & 0,57 & 0,83 \\
\hline sg & 0,34 & 0,38 & 0,21 & 0,25 & 0,24 & 0,46 & 0,31 & 0,29 & 0,25 & 0,23 & 0,28 & 0,35 \\
\hline
\end{tabular}

Ipẽ-roko

\begin{tabular}{|c|c|c|c|c|c|c|c|c|c|c|c|c|}
\hline $\mathrm{N}$ & 1,68 & 1,50 & 1,19 & 1,52 & 1,27 & 1,33 & 1,09 & 1,00 & 1,61 & 2,10 & 2,33 & 2,20 \\
\hline P & 0,06 & 0,05 & 0,07 & 0,07 & 0,05 & 0,09 & 0,09 & 0,10 & 0,06 & 0,13 & 0,09 & 0,10 \\
\hline K & 1,00 & 1,61 & 1,12 & 0,46 & 0,79 & 0,58 & 1,33 & 1.44 & 0,71 & 0,84 & 0,44 & 1,04 \\
\hline $\mathrm{Ca}$ & 2,00 & 1,98 & 1,50 & 2,24 & 2,90 & 2,09 & 2,54 & 2,19 & 1,25 & 0,98 & 1,57 & 1,48 \\
\hline$\therefore g$ & 0,34 & 0,41 & 0,27 & 0,27 & 0,32 & 0,28 & 0,31 & 0,20 & 0,27 & 0,23 & 0,30 & 0,35 \\
\hline
\end{tabular}

\begin{tabular}{lllllllllllllll}
\hline \multicolumn{10}{c}{ Misto } \\
\hline $\mathrm{N}$ & 1,81 & 1,63 & 1,57 & 1,51 & 1,73 & 1,46 & 1,12 & 1,40 & 1,32 & 1,76 & 1,72 & 1,76 \\
$\mathrm{P}$ & 0,05 & 0,05 & 0,07 & 0,05 & 0,06 & 0,08 & 0,07 & 0,08 & 0,04 & 0,13 & 0,08 & 0,07 \\
$\mathrm{~K}$ & 0,65 & 1,30 & 1,22 & 0,48 & 0,59 & 0,60 & 1,10 & 1,03 & 0,49 & 0,84 & 0,44 & 0,86 \\
$\mathrm{Ca}$ & 0,63 & 0,85 & 0,87 & 0,96 & 1,21 & 0,96 & 1,52 & 0,65 & 0,68 & 0,62 & 0,52 & 0,61 \\
& 0,63 & 0,30 & 0,23 & 0,25 & 0,24 & 0,30 & 0,31 & 0,22 & 0,26 & 0,26 & 0,25 & 0,23 \\
\hline
\end{tabular}


Tabela 12. Médias das Concentrações Mensais dos Elementos Quí micos Depositados no Solo Atravếs da Queda Das FoIhas (Porcentagem).

Elementos

Espëcies

$N$

P

K

$\mathrm{Ca}$

$\mathrm{Mg}$

\begin{tabular}{llllll}
\hline Angico & 2,06 & 0,07 & 0,31 & 0,67 & 0,15 \\
Aroeira & 1,72 & 0,07 & 0,60 & 0,81 & 0,25 \\
Cambará & 1,20 & 0,05 & 1,34 & 0,62 & 0,30 \\
Ipê-roxo & 1,57 & 0,08 & 0,94 & 1,89 & 0,30 \\
Misto & 1,57 & 0,07 & 0,80 & 0,84 & 0,29 \\
\hline
\end{tabular}

Tabela 13. Deposição Anual em $\mathrm{Kg} / \mathrm{Ha}$ de Nutrientes contidos nas Folhas nos Povoamentos Florestais Puros e Misto.

\begin{tabular}{lccccrr}
\hline $\begin{array}{l}\text { Elementos } \\
\text { Espécies }\end{array}$ & $\mathrm{N}$ & $\mathrm{P}$ & $\mathrm{K}$ & $\mathrm{Ca}$ & $\mathrm{Mg}$ & TOTAL \\
\hline Angico & 84,99 & 2,79 & 14,62 & 31,75 & 6,89 & 141,04 \\
Aroeira & 32,39 & 2,41 & 13,28 & 23,88 & 6,06 & 78,02 \\
Cambará & 57,12 & 2,11 & 59,51 & 30,16 & 13,80 & 162,30 \\
Ipê-roxo & 11,36 & 0,65 & 10,50 & 19,52 & 2,98 & 45,01 \\
Misto & 41,07 & 1,52 & 20,93 & 20,96 & 7,59 & 92,07 \\
\hline
\end{tabular}


o retorno dos nutrientes é mais acentuado no povoamento do cambară, em sua totalidade: Individualmente des taca-se o angico que devolveu $84,99 \mathrm{~kg} / \mathrm{ha} / \mathrm{ano}$ de nitrogênio.

A devolução do fósforo foi maior no povoamento de angico, 2,79 kg/ha/ano; já para o potássio o povoamento de cambarà sobressaiu-se com $59,51 \mathrm{~kg} / \mathrm{ha} / \mathrm{ano}$.

Quanto ao cálcio houve uma pequena preponderân cia do angico $(31,75 \mathrm{~kg} / \mathrm{ha} / \mathrm{ano})$ sobre o cambarä $(30,16 \mathrm{Kg} / \mathrm{ha} /$ (ano).

O destaque observado na devolução do nutriente magnësio coube ao cambará $(13,80 \mathrm{Kg} / \mathrm{ha} / \mathrm{ano})$ seguido pelo angi co $(6,89 \mathrm{Kg} / \mathrm{ha} / \mathrm{ano})$. 
5. DISCUSSÃO DOS RESULTADOS

5.1 Características silviculturais e dendrométricas

Quanto ao crescimento dos povoamentos em estudo notou-se que houve diferenças marcantes no que se refere aos valores dendrométricos, diferenças essas, já esperadas, pois as espécies que constituirram aqueles povoamentos apresen tam caracteristicas silviculturais distintas, de acordo com GURGEL FILHO (1975), NOGUEIRA (1977) e GURGEL et alii (1978).

o crescimento das espëcies florestais em estudo será discutido individualmente, possibilitando um melhor entendimento das caracteristicas silviculturais e fenolögicas de cada uma.

5.1.1 Angico

Essa espécie apresentou, atê o momento,o maior crescimento em altura e diâmetro, em relação às demais. O an- 
gico ê uma árvore de ocorrência natural da região, bastante comum nos cerrados do sudoeste paulista. O incremento médio anual verificado foi de $1,4 \mathrm{~cm}$ de diâmetro e $0,99 \mathrm{~m}$ de altura.

Os dados dendromëtricos observados até agora estão de acordo com RIZZINI (1971), pois esse autor afirma que aos 6 anos esta espécie pode atingir até $12 \mathrm{~cm}$ de diâmetro.

O crescimento observado do angico foi o melhor dentre as espécies estudadas, porēm o fuste é tortuoso, exige derrama artificial e até desbrota na base do tronco.

Após o desbaste efetuado em julho de 1978 houve brotação das touças, havendo necessidade de eliminá-las pạ ra abrir espaços para que as árvores remanescentes possam explorar melhor o solo em água e nutrientes, bem como receber maior insolação incrementando a atividade fotossintética.

o crescimento do angico no povoamento misto foi levemente superior ao do povoamento puro, conforme se observa na Tabela 8 , entretanto essa diferença não foi evidenciada na aplicação do teste " $t$ ".

O angico por ser uma espécie de madeira pesada, dura e resistente à deterioração, segundo RIZZINI (1971) e 
PIO CORREA (1974) tem largo emprego em construção de cercas de imōveis rurais. Por ocasião do primeiro desbaste, aos 7,5 anos de idade, foram retiradas as árvores fracas, tortuosas e defeituosas, otendo-se 456 moirões por hectare de $7 \mathrm{~cm}$ de diâmetro na ponta mais fina e $2,00 \mathrm{~m}$ de comprimento. O material restante que pode ser usado para lenha ou para a produção de carvão, totalizou 28,5 esteres/ha de madeira empi lhada correspondente ao corte de 950 ärvores por hectare.

Dependendo da finalidade da cultura do angico, pode-se plantá-lo em espaçamentos mais amplos do que $2,00 \mathrm{x}$ $2,00 \mathrm{~m}$, provocando assim, um primeiro desbaste mais tardio e por exemplo, pode-se recomendar o plantio do angico para pro dução de madeira para carvão, no espaçamento de 3,00 x 2,00 m ou seja, 1.666 plantas por hectare, aos 10 anos aproximadamen te se fará o corte raso obtendo-se um volume de madeira em torno de 200 esteres/ha. Tambēm é possivel conduzir esta floresta para obtenção de madeira para construção civil o que de mandará mais tempo e exigirá a prática dos desbastes periỏdicos.

Quanto aos aspectos fenolögicos o que se verificou corresponde às observações feitas por RIZZINI (1971).

Nas condições da presente experimentação o flo rescimento ocorreu nos meses de outubro-novembro e a frutifi- 
cação em maio-junho. As primeiras frutificações se deram aos 5 anos de idade nas árvores das bordaduras.

- angico, essência florestal tipicamente de terras de baixa fertilidade, deveria ser mais estudado, principalmente no que diz respeito ao melhoramento florestal, visando dentre outros aspectos a melhoria da forma da ărvore e a aceleração do crescimento.

\section{1 .2 Aroeira}

Em valores dendromëtricos o povoamento da Aroei ra teve um incremento mëdio anual da ordem de $0,9 \mathrm{~cm}$ em diâmetro e $0,8 \mathrm{~m}$ em altura.

Esses valores se assemelham aos da literatura uma vez que HERINGER e FERREIRA (1973) apontam um incremento mëdio anual para o diâmetro da ordem de $1,05 \mathrm{~cm} e$ NOGUEIRA (1977) encontrou os incrementos de $1,17 \mathrm{~cm} / \mathrm{ano}$ e $0,72 \mathrm{~m} / \mathrm{ano}$ em diâmetro e altura respectivamente.

A pequena diferença observada pode ser explica da alëm de outros fatores, pelas condições ecológícas diferen tes entre os ambientes estudados.

HERINGER e FERREIRA (1973) recomendam o plan- 
tio da aroeira atẻ mesmo em cexrados desde que se faça uma ca lagem prévia. Esta pode ser a razão do crescimento dispar entre a literatura citada e o observado, pois não foi feito calagem na época do plantio.

Nos dois primeiros anos houve necessidade de se fazer a desbrota das gemas basais para que houvesse defini çäo de um fuste principal. Alëm disso, ocorreu em algumas ärvores um envergamento da haste principal que exigiu atë um tutoramento para que as ärvores näo apresentassem muitas tor tuosidades na idade adulta.

o plantio da aroeira em povoamentos florestais jä formados poderia ser a solução para o envergamento e atẻ para a brotação excessiva das gemas basais.

GURGEL FILHO (3975) menciona o fato de haver espécies que apresentam ramificaça do tipo simpodial mesmo em espaçamentos apertados. Isto foi observado na aroeira que exige derrama periódica para que haja formação do fuste.

o florescimento da aroeira ocorre no inicio da primavera e a frutificação se dä logo em seguida pequenas variações de ano para ano, quanto à epoca da colheita de sementes. Normalmente as sementes são colhidas em mea dos de outubro. 
Por ocasião do desbaste, efetuado em 1978 reti rou-se 18,22 esteres/ha de madeira, sendo 10 est./ha de madei ra para cerca (repiques ou lascas) e o restante em lenha. Em nůmeros, o volume de madeira para cerca correspondeu a 52 repiques por hectare $\operatorname{com} 6$ a $8 \mathrm{~cm}$ de diâmetro na ponta mais fina.

A condução de um povoamento florestal cuja finalidade è a obtenção de madeira de grandes dimensões exige desbastes periódicos. No caso presente procurou-se retirar as ärvores de maneira que houvesse uma maior uniformidade entre todas as parcelas do experimento, portanto o nümero de ärvores cortadas dependeu basicamente da porcentagem de falhas de cada parcela de tal modo que o nümero de plantas após o desbaste fosse aproximadamente 60 \% do nümero inicialmente plantado.

Quando se comparou o crescimento da aroeira plantada em povoamento puro e no misto constatou-se uma difem rença significativa ao nivvel de $5 \%$ "pelo teste "t" "para os valores de altura da ärvore. Esse crescimento diferenciado pode ser atribuído à associação das espëcies que teria favore cido o crescimento em altura da aroeira, conforme METZ (1954), BISWELL et alii (1966), MC CLURKIN (1970) e FERRI (1974). PO de-se levantar a hipótese que a diversidade das espécies po deria propiciar uma maior exploração do local. 


\subsubsection{Cambará}

O incremento mẻdio anual do cambarä, nesses 10 anos de estudo, foi semelhante ao da aroeira, ou seja; 1, l cm /ano e 0,70 m/ano em diâmetro e altura respectivamente.

E uma espécíe que exige desbrota nos primei ros anos de idade, caso contrário haverá formação de toucei ras sem uma definição perfeita do tronco principal. Exige ain da a derrama artificial, pois é uma essência cujo tipo de rami ficação é simpodial.

Os moirôes de cerca obtidos por ocasião do pri meiro desbaste do cambarä apresentavam formas tortuosas o que dificultou a sua utilização.

Nas condições da presente pesquisa e experimen tação o florescimento tem ocorrldo em junho e julho e a prodü ção de sementes em agosto e setembro de cada ano.

A produção de madeira por ocasião do primeiro desbaste foi de 29,94 esteres/ha, sendo 16,94 esteres de le nha e 13,00 esteres de madeira para cerca, correspondendo a 325 repiques/ha.

o cambarâ, quando plantado em consociação com 
as demais essências florestais em estudo, apresentou um desen volvimento ligeiramente maior que em povoamentos puros, todavia essa diferença não foi constatada estatisticamente.

\section{1 .4 Ipê-roxo}

Foi a essência florestal que apresentou o menor incremento médio anual, correspondendo a $0,62 \mathrm{~cm}$ e 0,53 $\mathrm{m} / \mathrm{ano}$ em diâmetro e altura respectivamente. Esse desenvolvimento mais lento poderia ser explicado pelo fato de ser o ipê -roxo uma espécie mais exigente em nutrientes.

NOGUEIRA (1977), sem entrar em detalhes sobre a fertilidade do solo, observou um crescimento lento quando trabalhou com esta essência florestal. RIZZINI (1971), alerta para o fato da ocorrência ocasional desta espêcie em solos de cerrado, o que se depreende que o plantio desta espêcie é mais apropriado em solos mais fërteis.

Em 1975 ocorreu geada no local do experimento que causou sérios prejuízos ao desenvolvimento e à sobrevi vên cia de algumas plantas de ipê-roxo.

A formação e a condução de urna floresta homogê nea de ipê-roxo, exigem, à seme lhança das essências anteriormente descritas, präticas silviculturais que oneram os cus- 
tos de implantação de uma floresta.

Esta espécie ainda näo floresceu nas condições do presente experimento.

A execução do primeiro desbaste no povoamento homogêneo do ipê-roxo consistiu em um corte de limpeza, isto é, foram cortadas as ärvores dominadas. A quantidade do material lenhoso retirado foi desprezível.

o crescimento das ảxvores em maciços puros e mistos foi semelhante, com uma leve preponderência para a altura no povoamento misto, contudo o teste "t" aplicado não acusou diferença significativa.

\section{1 .5 Saguaragi}

Ess a essência florestal demonstrou uma grande susceptibilidade à geada, que causou a morte da parte aérea de todas as plantas, havendo, contudo, posteriormente regeneração das touças existentes.

o desenvolvimento dendromëtrico anterior à gea da de 1975 estava sendo superior ao do angico, pois com cinco anos de idade apresentou um incremento mẻdio anual de $1,22 \mathrm{~cm}$ e $1,16 \mathrm{~m}$ em diâmetro e altura respectivamente. 
Trata-se de uma espêcie que poderia ser planta da em solo de cerrado desde que na regĩão não ocorra geada:

o saguaragi destacou-se pelo räpido crescimento, pela ramificação do tipo monopodial, pelo fuste retili neo, pela derrama natural perfeita e pela cicatrização räpida dos nōs.

Essas caracteristicas silviculturais observadas aliadas â qualidade da madeira conforme RIZZINI (1971) e HUECK (1972), possibilitam a sua utilização para a produção de dormentes, postes e estacas.

O fato do saguaragi apresentar un fuste reto é, dentre as espécies em estudo, a que proporciona melhores alternativas para o uso da madeira.

No povoamento do saguaragi não foi efetuado ain da o primeiro desbaste porque as ârvores estão no estägio de regene ração vigorosa.

Da mesma forma que as outras espêcies estuda das, o desenvolvimento do saguaragi em povoamentos puros foi semelhante ao povoamento misto. 
5.2 Deposição das folhas

O estudo da ciclagem dos nutrientes de um ecos sistema florestal propicia ao silvicultor subsidios que poderão inclusive nortear as práticas desonômicas requeridas.

A maioria dos trabalhos publicados sobre o assunto destaca a importância desse estudo para explicar o comportamento e a tolerância das espécies, dentre outras caracte rísticas silviculturais, visto que existe uma relação entre produção de matêría orgânica e dominâncìa das essências florestais.

O estudo completo de todas as entradas e safdas de nutrientes de um ecossistema florestal implica em um período de tempo relativamente grande alêm do aspecto econômi co envolvente.

Entretanto, devido às restrições de tempo o presente estudo procurou enfocar apenas um periodo de doze me ses pesquisando o principal componente que forma a manta flo restal, representado, pelas folhas caídas no solo, que segundo COZZO (1974), GESSEL e TURNER (1974) e LANG (1974), respon de por 70 a 80 \% da matëria orgânica depositada.

A presente pesquisa reveste-se de carăter qua- 
se pioneiro visto que os estudiosos do assunto têm se preocu pado preponderantemente com espécies florestais introduridas ou com florestas naturais.

Os resultados obtidos poderão servir de parâme tros para uma comparação com os dados que estão sendo observa dos nos estudos com as essências florestais exöticas, amplamente utilizadas em florestamento e reflorestamento.

A deposição de folhas foi apresentada na Tabela 9, a qual contẻm o peso das folhas caídas por hectare durante o ano de 1977. Percebe-se, claramente, uma variação entre os povoamentos estudados. Essa variação já foi detectada por diversos pesquisadores tais como THAMES (1962), que encon trou diferentes deposições quando trabalhou com Pinus taeda e Pinus echinata que apresentaram, respectivamente, deposições anuais de folhas da ordem de $2.210 \mathrm{~kg} / \mathrm{ha}$ e $280 \mathrm{~kg} / \mathrm{ha}$.

Os trabalhos de COZZO e RIVELOS (1971), HURD (1971L, Cozzo (1972) e (1974) evìdenciam também a exìstêncìa de variações nas deposições totais das essências que eles pes quisaram, alêm da varíação sazonal, tambẻm constatada no presente trabalho.

A partir da Tabela 9 elaborou-se a Tabela 14 que apresenta as quantidades de folhas depositadas no solo nas quatro estações do ano de 1977. 
Tabela 14. Deposição das Folhas em Kg/ha Nas Quatro Estações do Ano de 1977.

\begin{tabular}{lrrrrr}
\hline $\begin{array}{c}\text { Estações } \\
\text { do } \\
\text { Ano }\end{array}$ & Angico & Aroeira & Cambará & Ipê-roxo & Misto \\
\hline Primavera* & 950,00 & 205,68 & $1.521,13$ & 303,00 & 505,54 \\
Verão & $1.117,58$ & 831,54 & 761,87 & 400,05 & 619,80 \\
Outono & $1.133,08$ & $1.187,90$ & 892,10 & 186,50 & 812,00 \\
Inverno & $1.180,00$ & 71,50 & $1.576,00$ & 90,20 & 678,88 \\
\hline TOTAL & $4.380,86$ & $2.296,62$ & $4.751,10$ & 979,75 & $2.616,22$ \\
\hline
\end{tabular}

A deposição de folhas no povoamento do angico foi uniforme nas quatro estações do ano, já para a aroeira a maior deposição ocorreu no outono, correspondendo a 52 음 do total anual. A deposição das folhas no povoamento do cambarä se destacou pela existência de dois picos: um na primavera e outro no inverno.

A menor deposição de folhas entre as quatro espëcies estudadas ocorreu no povoamento de ipê-roxo, o que coincide com o seu inexpressivo desenvolvimento dendromëtrico.

De uma maneixa geral, houve uma relação direta entre o crescimento das espêcies e a quantidade de folhas de-

(*) Primavera: compreende os meses de setenbro, outubro e nom vembro. 
positadas no solo. Essa relação tambëm foi apontada por THAMES (1962) e GESSEL e TURNER (1974).

A deposição de folhas das espécies estudadas pode ser relacionada com a precipitação, como se visualiza nas Figuras de nümeros 4 a 8 .

No povoamento do angico a máxima deposição de folhas ocorreu nos meses de menor precipitação. A queda de fó Ihas no povoamento da aroeira mostrou um pico nos meses mais secos do ano de 1977. Jä no povoamento de cambarä houve um fá to interessante, ocorrido no mês de novembro, quando se verificou a menor deposição de folhas, contrastando com os meses de setembro, outubro e dezembro durante os quais foi registra da uma elevada deposição foliar.

A máxima queda das folhas no povoamento do ipê -roxo ocorreu no mês de fevereiro, que apresentou uma precipí tação de $80 \mathrm{~mm}$. Houve posteriormente um decrêscimo gradativo na produção de folhas atê atingir um mỉnimo no mês de dezembro.

o povoamento misto apresentado na Figura 8, como é constituỉdo das quatro espëcies em estudo, teve uma de posição foliar uniforme durante o ano independentemente da distrỉbuição anual das chuvas. 
As variações verificadas entre as essências florestais em estudo ê perfeitamente explicâvel pois elas são quatro espécies botânicas diferentes, com caracterïsticas fenológicas prôprias. Aliás, este fato ê corroborado por vários pesquisadores destacando-se cozzo (1974), que encontrou uma máxima produção de folhas, em povoamentos de Pinus canariensis na primavera, e em talhões de Eucalyptus camaldulensis no verão.

Em condições brasileiras deverse mencionar as pesquisas de POGGIANI (1979) e de CARPANEZZI (1980). O primei ro, trabalhando com Pinus caribaea var. hondurensis e Pinus oocarpa, observou uma maior deposição de folhas no periodo se co do ano, correspondendo ao inverno. CARPANEZZI estudou a de posição de folhas em un povoamento de Eucalyptus spp e observou que a maior queda de folhas ocorreu no verão, coincidindo com os meses de maior pluviosidade.

Do trabalho de COzzo (1972) pode-se destacar a relação direta entre a deposição de folhas e precipitação havida, pois esse autor registrou no mês de janeiro de 1971 uma deposição de $1.253 \mathrm{Kg}$ /ha de aci̊culas de Pinus canariensis, pa ra uma precipitação igual a $294 \mathrm{~mm} ;$ no ano de 1972, tambêm no mês de janeiro, a deposição de acĩculas fol de apenas $259 \mathrm{~kg} /$ ha e a precipitação de 29 mm. 
A vista destas observaçôes pode-se concluir que uma correlação mais confiẫvel entre precipitação pluviométri ca e deposição foliar de uma determinada espécỉe poderia ser feita, desde que os dados sejam coletados por periodos mais prolongados (três a quatro anos).

Comparandorse os resultados obtidos na presente experimentação com aqueles obtidos por PoGGIANI (1979), ve rifica-se que o Pinus oocarpa e o Pinus caribaea var. hondurensis depositaram uma maior quantidade de matēria orgânica no solo (respectivamente 7.640 e $9.943,4 \mathrm{~kg} / \mathrm{ha} / \mathrm{ano}$ ) do que as espëcies em estudo. Este fato ê explicado pelo maior desenvol vimento dendromêtrico dessas pinâceas em relação âs essências nativas.

Trabalhos complementares deverão ser feitos, visando conhecer a velocidade de decomposição da matéria orgâ nica depositada no solo tanto das espécies introduzidas como das essências nativas.

5.3 Concentração de nutrientes das folhas depositadas no solo

BARROS E BRANDI (1975), citando RALSTON e PRIN CE (1265) e RENNIE (1965), comentam que a maior concentração de nutrientes ocorre nas ärvores da seguinte forma: folhas > 
galhos menores $>$ galhos matores? tronoo.

BARTOS e JOHNSTON (1978), também afirmam que as malores concentugcoes dentugento, tostoro, potásio e magnêsilo são encontradas nas tolnas.

Pelas razoes anderiormente apontadas, procedeu neste experimento, a coleta, pesagem e anălise quỉmica somente das folhas, que calram no solo duxante o ano de 1977.

A análise quimica fol mensal e se ateve ao nitrogênio, fóstoro, potássio, cálcio e magnésio. Os teores encontrados foram mostrados nas Tabelas 11 e 12 .

Do exame dessas tabelas percebe-se daramente a grande variaça entre as concentraçoes de rutrientes durante o ano para a mesma espécle, e entre as espëcles.

Essas yaxiaços jä foram constatadas por diverm sos autores como por exemplo TARRANT (1951), que aponta as condiçöes de solo, estaçoes do ano, tipos de vegetals (folhosas e coniferasl como fatomes tesponsaveis pela ocorrencia da variabilidade dos teores de nutrientes da manta floresta. A Tabela I motra al guns dado observados pot diferentes pesquisadores, evidenciando mais una vez as disparidades de conoen traçöes de nutrientes nas folhas das plantas. 
BARROS E BRANDI (1975) tambẻm apontaram uma di ferenciação nos teores de fôsforo, potássio, câlcio, magnésio, aluminio e ph, quando analisaram a manta florestal de três povoamentos constituludos pela Joannesia princeps (andä-açu), zeyheria tuberculosa (ipê-pretol e pinus elliottii.

A quantidade de nutrientes em $\mathrm{Kg} / \mathrm{ha}$ apresentada na Tabela 13 foi calculada a partir dos teores dos nutrien tes analisados e as quantidades totais das folhas coletadas durante $O$ ano de 1977.

A quantidade de nitrogênio devolvida ao solo foi maior no povoamento do angico, seguido pelo cambarä.

o povoamento do angico destacourse pela maior deposição anual de nitrogênio, fösforo e cálcio.

o povoamento do cambarä devolveu ao solo uma maior quantidade de potâssio e magnêsio.

A associação das quatro espêcies que resultou no poroamento misto, no que diz respeito à quantidade de nutrientes devolvidos, ocupam uma posição intermediảria em rela f̧ão aos povoamentos puros. 
GOSz et alii (1972) afirmam que a extrema variabilidade encontrada na devolução de nutrientes ao solo é o resultado da diferença entre as espêcies, entre tecídos botânicos dessas mesmas espécies e devìdo a variação sazonal. Ain da segundo esses autores, uma queda prematura das folhas e das flores das plantas pode aumentar o teor de elementos móveis como fôsforo, potâssio e nitrogênio na manta florestal.

5.4 Povoamentos florestais puros e mistos

Dentre os parâmetros pesquisados, nota-se que a velocildade de crescimento das diversas espêcies, tanto nos povoamentos puros como no povoamento misto, atê o presente, ê semelhante. Conclui-se, então, que não houve vantagem do ponto de vista dendromêtrico a formação dos povoamentos mistos. Em relação à deposição de folhas, o povoamento misto apresentou uma posição intermediāria entre os povoamentos puros, tanto qualitativa como quantitativamente.

A formação de florestas homogêneas ou heterogê neas $\hat{e}$ assunto bastante discutido atualmente, porêm são escas sos os trabalhos cientificos sobre o assunto.

A implantação de um projeto de pesquisa com es ta Iinalidade ê muito complexa, tendo em vista a gama enorme de variâveis envolvidas, aliada ã dificuldade de comparação 
entre os dois tipos de povoamentos florestais. o povoamento puro é mais interessante economicamente, e o misto, biologica mente.

Do ponto de vista blológico a distribuição anual uniforme da queda das folhas do povoamento misto, em re lação aos povoamentos puros, (Figura 8) permite que o horizon te superficial do solo permaneça recoberto pela manta florestal durante todas as êpocas do ano.

Do ponto de vista silvicultural, outro aspecto importante verificado neste trabalro é a necessidade de se utilizarem essências nativas de crescimento mais rápido como o angico e o saguaragi, que possam atuar como espëcies pionei ras que provocam um räpido sombreamento, contribuíndo para a definição do fuste das espécies de crescimento mais lento e de ramificação simpodial. Essa necessidade jâ foi verificada por GURGEL FILHO (1976) que afirma: "O que aflue, o que emerge, é a necessidade impostergåvel da constituição de povoamen tos mistos para as essências indígenas de ramificação cimosa, pois só desta forma será exequível a obtenção de indivĩduos com facies florestal". 


\subsection{Considerações finais}

o crescimento comparado das essências florestais permitiu apontar o angi.co como a espêcie que apresentou o desenvolvimento mais râpido, seguido do saguaragi e da aroeỉra. Essas três espécies possuem potencialidades, quanto ao uso das suas madeiras, para moirôes de cerca, postes e dormen tes. Cabe ressalvar a grande susceptibilidade do saguaragi a geadas, o que restringe a sua indicação para o reflorestamento nas áreas onde este fenômeno possa ocorrer, mesmo que de forma esporảdica.

o ipê-roxo, pelo crescimento moroso, e o camba râ pela forma indesejăvel que adquîre, requerem um maior nüne ro de informações, no que se refere a uma possĩvel recomendação para a formação de florestas.

De maneira geral, o presente estudo preocupou-se com as potencialidades inerentes a cada uma das essências florestais pesquisadas, visando dar uma contribuição para o melhor conhecimento das espêcies florestais brasileiras.

Nẫo restam dữvidas que grandes linhas de pesquisa devem ser conduzidas com relação ao melhoramento genétí co, à plasticìdade, â frugalidade, â tolerência, aos tipos de ramificação, â nutrição mineral, ao manejo florestal, aos pe- 
rlodos de tempo requertdos para a exploração e à economicidade dos empreendimentos lorestais com espêcies indigenas. 


\section{CONCLUSÕES}

Os resultados obtidos com a pesquisa e experimentação proporcionaram informaçōes valìosas, para a formação de povoamentos florestais de essências nativas, as quais são resumidas a seguir:

1 - o crescimento dendrométrico das espécies obedeceu â seguinte ordem decrescente: angìco, cambarâ, aroei ra, saguaragì e ìpê-roxo:

2 - o povoamento misto ocupou a posição intermediäria tanto em crescimento denaromëtrico como na deposição de folhas;

3 - o crescimento dendromêtrico das espëcies no povoamento misto e nos povoamentos puros näo díferiu estatisticamente, exceto para o crescimento em altura da aroeira; 4 - Das espêcîes estudadas apenas uma apresen tou crescimento monopodial, ou seja, o saguaragi que possui uma derrama perfeita; 
5 - O saguaragi foi susceptivel à geada:

6 - o angico, a aroeira, o cambarä e o ipêr-roxo apresentaram crescimento simpodial o que dificulta e onera a formação de povoamentos florestais, pois exigem derrama artificial;

7 - O cambarä. devido à sua capacidade de deposição de matéria orgânica no solo, pode ser usado para o plantio em consociação com outras espécies:

8 - A deposição de matéria seca em quilos por hectare foi maior no povoamento puro do cambará seguido do an gico, do misto, da aroeira e por ültimo do ipê-roxo;

9 - Em termos médios os povoamentos puros depo sitaram no solo maior quantidade de matéria seca do que o povoamento misto, 258,51 e $218,02 \mathrm{~kg} / \mathrm{ha} / \mathrm{mês}$ respectivamente;

10 - Quanto aos teores de nutrientes devolvidos ao solo, através das folhas dos povoamentos florestais em estudo, constatou-se que o angico possui a maior concentração em nitrogênio $(2,06 \%)$; o cambară o maior teor em potássio $(1,34 \%)$ e em magnésio $(0,30 \%)$; 0 ipê-roxo apresentou maior teor em Ca (1,55 \%). O teor de fósforo foi semelhante a todos os povoamentos;

11 - Para as espécies estudadas houve uma rela ção direta entre o crescimento dendrométrico e a deposição de folhas no solo:

12 - Os povoamentos puros das espécies em estudo não tiveram o mesmo comportamento entre si em relação à de 
posição de folhas durante as diferentes ëpocas do ano;

13 - A queda das folhas no povoamento misto dis tribuiu-se uniformemente durante o ano de 1977. 


\section{LITERATURA CITADA}

ACOSTA, A.C., 1964. A preliminary study of organic detritus in a tropical forest ecosystem. Revista Biologia Tropical. Costa Rica. 12(2): 175-215.

ARAUJO, V.C., 1970. Fenología de essências florestais amazôni cas I. Boletim do I.N.P.A. Manaus, (4): 1-25. (Série Pesqui sas Florestais).

ASHTON, D.H., 1975. Studies of litter in Eucalyptus regnans forests. Australian Journal Botanic. Melboume, 23:413-33.

BARROS, D.P., 1970. Ensaio de espaçamento inicial para aroei-ra. Silvicultura em São Paulo. Instituto Florestal. 7:39-41.

BARROS, N.F. e R.M. BRANDI, 1975. Influência de três espécies florestais sobre a fertilidade de solo pastagem em Viçosa. M.G. Brasil Florestal. Rio de Janeiro. 6(24):24-9. 
BARTOS, D.L. e R. JOHNSTON, 1978. Biomass and nutrient content of Chuakin Aspen at two sites in the Western United States. Forest Science. Washington. 24(2):273-080.

BISWELL, H.H., R.P. GIBBENS e H. BUCHANAN, 1966. Litter pro duction by big trees and associated species. California Agriculture. California: 5-7.

BLANCO, H.G. e H. GODOY, 1967. Carta das chuvas do Estado de São Paulo. Instituto Agronômico de Campinas.

BRASIL. Ministério da Agricultura. Centro Nacional de Ensino e Pesquisas Agronómicas. Comissão de Solos. 1960. Levantamento e Reconhecimento dos Solos do Estado de são Paulo. Contribuição â Carta de Solos do Brasil. Boletim do Servigo Nacional de Pesquisas Agronômicas. Rio de Janeiro. 12:634p.

CABRERA, A.L., 1971. Revision del genero Gochnatia. Revista del Museo de La Plata. Argentina. 12(66):1-160.

CARVALHO FILHO, A.P. e L.C.T. MARQUES, 1979. Seleção de espécies promissoras para atividade de reflorestamento em função das caracterĩsticas silviculturais. Relatörio Técnico de Avaliação Preliminar. Brasil Florestal. Rio de Janeiro. $37: 72-87$. 
CARPANEZZI, A.A., 1980. Deposição de material orgânico e nutrientes em uma floresta natural e em uma plantação de Euca lyptus no interior do Estado de São Paulo. Piracicaba / ESALQ /USP, 107 p. (Dissertação de Mestrado) .

CENTRO DE PESQUISAS FLORESTAIS DA REGIÃO DE CERRADO. PRODEPEF, 1976. Estudos silviculturais de essências nativas da região de cerrado. Projeto no 8052-2. Série Divulgąão. Brasília: 45-8 .

CozZO, D., 1972. Registro de la hojarasca caída en el suelo de una plantacion joven de Pinus canariensis. Revista Fores tal Argentina. $16(3-4): 102-4$.

COZZO, D., 1974. La cantidad de materia orgânica depositada en el suelo por una plantacion de Robinia pseudoacacia. Re vista Forestal Argentina, (18) 3:67-9.

COZZO, D. e M.H.C.K. RIVEROS, 1971. Registro de la caída de matéria orgânica y elementos minerais de una plantacion de ocho anös de Eucalyptus camaldulensis. Revista Forestal Argentina, $15(1): 5-7$.

DAUBENMIRE, R., 1953. Nutrient content of leaf litter of trees in the Northern Rocky Mountains. Ecology. Brooklin U.S.A. $34(3): 786-90$. 
DUBOIS, J., 1970. Características e distribuição geográfica das florestas naturais de folhosas. Reflorestamento para produção de madeira de serraria. Tendências e possibilidą des. Sizvicultura em São Paulo. Instituto Florestal, ?:111-26 .

FERRI, M.G., 1974. Ecologia-Temas e Problemas Brasizeiros. Editora. U.S.P. são Paulo. 188 p.

FREITAS, F.G. e C.O. SILVEIRA, 1977. Principais solos sob a vegetação de cerrado e sua aptidão agrícola. In: IV Simpósio Sobre o Cerrado. Belo Horizonte, 1976. Editora U.S.P. São Paulo. 155-194.

GARG, R.K. e L.N. VYAS, 1975. Iitter production in deciduos Forest Near Udaipur-India. In: GOLLEY, F.B. e E. MEDINA, ed. Tropical ecological systems. New York, Springer-Verlag. p. $131-6$.

GARRIDO, M.A.O.; A.C.M.F. SIQUEIRA; J.B. BAITELLO; O.C. NEGREI ROS; C. BARBOSA, 1978. Programa de pesquisa e experimentação com essências indígenas no âmbito do Instituto Florestal do Estado de São Paulo. 30 Congresso Florestal Brasilei ro. Manaus. 232-4. 
GESSEL, S.P. A J. TURNER, 1974. Litter production by red alder in Western Washington. Forest Science. Washington 20(4):325-30 .

GOSZ, J.R.; G.E. LIKENS; F.H. BORMAN, 1972. Nutrient content of litter fall on the Hubbard Brook Experiment Forest, New Hampshire. Ecology. Brooklin U.S.A., 53(3):669-784.

GURGEL FILHO, O.A., 1976. Contribuição à silvicultura das espécies nativas. Instituto Florestal. São Paulo. 42 p.

GURGEL FILHO, O.A., 1975. Essências nativas. Silvicultura em São Pauzo. Instituto Florestal. 9:47-52.

GURGEL FILHO, O.A.; L.M.A. GURGEL GARRIDO e S.M. RODRIGUES NE TO, 1978. Características silviculturais e biomëtricas do crescimento de algumas essências da zona temperada. Anais do 30 Congresso Florestal Brasileiro. Manaus, 60-81.

GURGEL FILHO, O.A. e X.P. PASZTOR, 1963. Fenologia e comporta mento em alfobre de espẻcies floxestais e ornamentais. Silvicultura em São Paulo. Instituto Florestal. 1(2):291-304.

GURGEL FILHO, O.A. e J.L. MORAIS, 1972. Características silvi culturais e competição entre nove espëcies indígenas e uma exótica. Instituto Florestal. São Paulo. 21 p. (mimeografadol. 
HERINGER, E.P. e M.B. FERREIRA, 1973. Aroeira, Gonçalo-Alves e gibatão: O gênero Astronium e sua importância florestal. Cerrado. Brasilia, 22:24-33.

HUECK, K., 1972. As Florestas da Amërica do Sul. Editora Universidade. Brasi̊lia. $466 \mathrm{p}$.

HURD, R.M., 1971. Annual Tree - Litter production by successional forest stands. Juneau. Alaska. Ecology. Brooklin U.S.A., $52(5): 881-4$.

JORDAN, C.F. e J.R. KLINE, 1972. Mineral cycling: some basic concepts and their application in a tropical rain forest. Annual Revue Ecology Systematies. Palo Alto, 3:33-50.

KL INE, H. e W.A. RODRIGUES, 1968. Litter production in an area of amazonian terra firme forest. Part I. Litter fall organic carbon and total nitrogen centents of litter. Amazonian Kiez. 1:287-302.

KLINE, H, e W.A. RODRIGUES, 1968. Litter production in an area of amazonian terra firme forest. Part II. Mineral content of litter. Amazonian Kiel. I 44[303-10,

KORNÁS, A.M., 1970. Litter production. In: Proceedings of the Paris Symposium organized by UNESCO and the International Biological Programme. Paris. $139-43 \mathrm{p}$. 
KRAMER, J.P. E T.T. KOSLOWSKI, 1960. Physiology of Trees. New York. Mac Gross Hill Edition. 642 p.

LANG, G.E., 1974. Litter dynamics in a mised oak forest on the New Jersey Piedmont. Bulletin of the Torrey Botanical club. New York. 101(5):277-86.

MC CLURKIN, D.C., 1970. Site rehabilitation under planted redcedar and pine. In: Youngberg, C.T. Ed: Tree growth and forests soils. Corvallis, Oregon State University Press. $527 \mathrm{p}$.

METZ, L.J., 1954. Forest floor in the Piedmont region of South Carolina. Soil Science Society Proceedings. Madison, USA. 335-8.

NOGUEIRA, J.C.B., 1977. Reflorestamento heterogêneo com essências indígenas. Boletim Tëenico. Instituto Florestal. São Paulo. $24: 77 \mathrm{p}$.

NOGUEIRA, J.C.B. e A.C.M.F. SIQUEIRA, 1976. Ensaio de espaçamento de ipê-amarelo da mata virgem (Tabebuia velzosoi Tol et Schl. Sizvicultura em são Pauzo. 10:55-9.

ODUM, E.P., 1973. Fundamentos de Ecologia. Fundação Gulbenkian. Lisboa. $595 \mathrm{p}$. 
PATRIC, J,H. e D.W. SMITH, 1975. Forest management and nutrient cycling in eastern hardwoods. U.S.D.A. Forest Research Paper. NE 234. 12 p.

PICKEL, B., 1951. Fundar florestas mistas deve ser o objetivo do reflorestamento na silvicultura nacional, Instituto Florestal. São Paulo. 25 p. (mimeografado).

POGGIANI, F., 1976. Ciclo de nutrientes e produtividade de flo resta implantada. Silvicultura. São Paulo. $1(3): 45-48$.

POGGIANI, F., 1978. Adaptação ecológica, crescimento e desenvolvimento dos pinheiros tropicais. Boletim Informativo. Pro jeto de Pinheiros Tropicais, Piracicaba (3):1-10.

POGGIANI, F.; H.M.T.Z. do COUTO e J.W. SIMÕES, 1979. Aspectos ecológicos das mini-rotações e do aproveitamento dos resíduos florestais. Circular Técnica. I.P.E.F. Piracicaba, 74. 7 p.

PRIMO, B.L., 1968. Madeiras Comerciais Brasileiras. I.P.T. São Paulo. 875 p. 
PRITCHET, W.I., 1976. Properties and Management of Forest Soils. John willey \& Sons. Inc. Nova York. 500 p.

REVERSAT, F.B., 1976. A Trial comparison of cycles of mineral elements in plantation and natural forest growth of Framiré (Terminalia ivorensis) in the Ivory coast. Revue Bois et Forêts des Tropiques. 167:25-38.

RIZZINI, C.T., 1971. Arvores e Madeiras Oteis do Brasil. Manual de Dendrologia Brasileira. Editora U.S.P. São Paulo. 294 p.

RIZZINI, C.T., 1977. Arvores e Madeiras do Brasil. Instituto Brasileiro de Geografia e Estatistica - SUPREN. Rio de Janeiro. $86 \mathrm{p}$.

RIZZINI, C.T. e W.B. MORS, 1976. Botânica Econômica Brasizeira. São Paulo. Editora U.S.P. 207 p.

RIZZO, J.A.; A.J. CENTEMO; J.S. LOUSA E T.S. FILGUEIRAS, 1971. Levantamento de dados em âreas de cerrado e da floresta caducifoliada tropical do planalto centro-oeste. In: III Simpósio Sobre o Cerrado. São Paulo. Editora Edgard Blucher e Editora da Universidade de Brasilia. 103-09.

SARRUGE, J.R, e H.P. HAAG, 1974. Anălises Quimicas em Plantas. Piracịcaba. Depto Quİmica da E.S.A.L.Q. U.S.P. 56 p. 
SHAPLAND, R.E., 1974. Hardwood Plantation. Quaterly Journal of Forestry. Londres. Inglaterra. 68(3):218-22.

SPAIN, A.V., 1975. Aspects of the Role the Soil Biota in Forest Litter Decomposition. Australian Forestry. Canberra. $38(3): 171-6$.

SPURR, S.H. e V.B. BURTON, 1973. Forestry Ecology. Nova York The Ronald Press Company. $571 \mathrm{p}$.

THAMES, J.L., 1962. Litter production as influenced by species of Southern Pine. Journal of Forestry. Washington D.C. 60: 565 .

TARRANT, R.F.; L.A. ISAAC e R.F. CHANDLER, 1951. Observations on litter fall and foliage nutrient content of some Pacific Northwest tree species. Journal of Forestry. Washington D. C. $49: 914-5$.

VEIGA, A.A., 1976. Curso de Atualização Florestal. São Paulo. Instituto Florestal. 341 p.

WAIDE, J.B. e W.T. SWANK, 1975. Nutrient recycling and the stability of ecossystems. Implications for forest management in the Southeastern U.S. America's Renewable Resource Potencial. 1975. The Turning Point. In: Proceedings of National Convention Society of American Foresters. 404-24. 
WALTER, H., 1979. Vegetation of the Earth. New Yoxk. Springer-Verlag New York Inc. 2nd Ed. $274 \mathrm{p}$.

WEBB, L.J.: J.G. TRACEY, W.T.WILLIANS e G.N. LANCE. 1969. The pattern of mineral return in leaf litter of tree subtropical Australian Forests. Melbourne. Australian Forest ry. $33: 99-110$.

ZAVITKOSVSKI, J. e N. NEWTON, 1971. Litter fall and littex aC cumulation in red alder stands in Western Oregon. Plant and Soiz. Holand. Wageningen. 35:257-68. 